NBER WORKING PAPER SERIES

\title{
SCHOOL COMPETITION AND EFFICIENCY WITH PUBLICLY FUNDED CATHOLIC
} SCHOOLS

David Card

Martin Dooley

Abigail Payne

Working Paper 14176

http://www.nber.org/papers/w14176

\author{
NATIONAL BUREAU OF ECONOMIC RESEARCH \\ 1050 Massachusetts Avenue \\ Cambridge, MA 02138 \\ July 2008
}

We are particularly grateful to Olesya Vovk and our research assistants in the Public Economics Data Analysis Laboratory. We also thank Joseph Altonji, Todd Elder, David Green, Philip Haile, Steven Jones, Patrick Kline, Patrick McEwen, Derek Neal, Craig Riddell, Arthur Sweetman, and many other seminar participants for helpful comments on earlier drafts. This research has been funded from grants from the Canadian Foundation for Innovation, the Ontario Innovation Trust, the Social Sciences and Humanities Research Council, the Council of Ministers of Education, and McMaster University. The views expressed herein are those of the author(s) and do not necessarily reflect the views of the National Bureau of Economic Research.

NBER working papers are circulated for discussion and comment purposes. They have not been peerreviewed or been subject to the review by the NBER Board of Directors that accompanies official NBER publications.

(C) 2008 by David Card, Martin Dooley, and Abigail Payne. All rights reserved. Short sections of text, not to exceed two paragraphs, may be quoted without explicit permission provided that full credit, including $\odot$ notice, is given to the source. 
School Competition and Efficiency with Publicly Funded Catholic Schools

David Card, Martin Dooley, and Abigail Payne

NBER Working Paper No. 14176

July 2008

JEL No. I21

\begin{abstract}
$\underline{\text { ABSTRACT }}$
The province of Ontario has two publicly funded school systems: secular schools (known as public schools) that are open to all students, and separate schools that are open to children with Catholic backgrounds. The systems are administered independently and receive equal funding per student. In this paper we use detailed school and student-level data to assess whether competition between the systems leads to improved efficiency. Building on a simple model of school choice, we argue that incentives for effort will be greater in areas where there are more Catholic families, and where these families are less committed to a particular system. To measure the local determinants of cross-system competition we study the effects of school openings on enrollment growth at nearby elementary schools. We find significant cross-system responses to school openings, with a magnitude that is proportional to the fraction of Catholics in the area, and is higher in more rapidly growing areas. We then test whether schools that face greater cross-system competition have higher productivity, as measured by test score gains between 3rd and 6th grade. We estimate a statistically significant but modest-sized impact of potential competition on the growth rate of student achievement. The estimates suggest that extending competition to all students would raise average test scores in 6th grade by 6-8\% of a standard deviation.
\end{abstract}

David Card

Department of Economics

549 Evans Hall, \#3880

UC Berkeley

Berkeley, CA 94720-3880

and NBER

card@econ.berkeley.edu

Martin Dooley

1280 Main Street West

Hamilton, Ontario L8S 4M4

Canada

dooley@mcmaster.ca

\author{
Abigail Payne \\ Department of Economics \\ McMaster University \\ KTH 426, 1280 Main Street West \\ Hamilton, Ontario, Canada L8S 4M4 \\ paynea@mcmaster.ca
}


Faced with budgetary pressure and growing concerns over student achievement, policy makers around the world are struggling to raise the efficiency of public schools. ${ }^{1}$ Starting with Friedman (1955) many economists have argued that a cost-effective way to boost performance is to limit the monopoly power of local school districts. For this prescription to work, families have to be able to choose between schools, and be willing to switch schools to access higher quality education. School administrators also have to be rewarded for producing the quality features that parents demand. So far, choice initiatives enacted in the U.S. have gone only part way toward satisfying these conditions. ${ }^{2}$

Alternatives to the local monopoly model have a much longer history outside the U.S. ${ }^{3}$ In this paper we study competition among elementary schools in Ontario, Canada, which for over a century has operated two publicly funded school systems: secular schools (known as public schools) that are open to all students, and separate schools that are open to children with Catholic backgrounds. ${ }^{4}$ The two systems are administered independently and receive equal funding per student.

For non-Catholics, the Ontario system functions like a typical public system in the U.S. For the roughly $40 \%$ of children with Catholic backgrounds, however, the system is essentially a voucher program with two competing suppliers. Though choice is limited to Catholics, competition between the systems can potentially improve the quality of schooling available to all students. Measuring the size of these potential gains is important not only for understanding the

\footnotetext{
${ }^{1}$ See Hanushek (2003) for an overview of trends in school spending and achievement in various countries.

${ }^{2}$ Two main initiatives to loosen the control of local school districts are charter schools and school vouchers. See Hoxby (2004), Booker et al. (2005) Bifulco and Ladd (2004) and Carnoy et al (2005) on the issue of charter schools, and Howell and Petersen (2002), Krueger and Zhu (2003) and Ladd (2002) on the issue of vouchers.

${ }^{3}$ Clark (2005) studies the efficiency of English high schools that opt out of local school district control, while Gibbons, Machin, and Silva (2006) analyze competition between public schools in England. Ahlin (2003) studies the effects of competition in Sweden. Hsieh and Urquiola (2006) study the voucher system in Chile.

${ }^{4}$ More precisely, we study the incentives for administrative effort and efficiency when students can choose between school systems. We follow the literature in referring to this as "school competition."
} 
Ontario system, but also for analyzing proposed choice systems in other settings. The impacts of competition in the Ontario system presumably represent a lower bound on the efficiency gains that could be realized in a more general system.

We begin by outlining a simple model of school choice and effort competition between public and separate schools. Assuming that Catholic enrollment in public schools depends on the quality gap between the local public and separate schools, and that the managers of the competing systems are rewarded for larger market shares, the model implies that equilibrium effort will be higher in markets with a larger share of Catholics, and where Catholic parents are less committed to a particular environment (religious or secular) at school.

To identify the neighborhood characteristics that lead to greater incentives for effort competition, we study the effects of elementary school openings and closings on enrollment trends at nearby schools. We find that the opening of a new school by the rival system leads to enrollment losses of $6-10 \%$ over the next three years. The cross-system losses are approximately proportional to the fraction of Catholic families in the area, and are larger in rapidly-growing areas where families have weaker ties to specific schools.

We then evaluate the effect of enhanced competition on student achievement, using standardized tests that are administered province-wide to $3^{\text {rd }}$ and $6^{\text {th }}$ graders. We develop an econometric model for the test score gains of a cohort of students at a given school that depends on student and local area characteristics, and on an indicator of cross-system competition derived from our enrollment growth model. A key identifying assumption is that variation in the fraction of Catholic families in the surrounding neighborhood has no direct effect on test score gains of students, though it affects the sensitivity of enrollment demand to relative school quality. We present evidence suggesting that Catholic parents and children have similar characteristics to 
Protestants, although both groups differ from those with no religious affiliation (who have lower parental education and lower student test scores). Thus, our preferred specifications measure the effect of changes in the degree of cross-system competition, holding constant the fractions of groups other than Catholics or Protestants.

We estimate modest but statistically significant impacts of enhanced effort competition on the growth rate of mathematics and reading achievement between $3^{\text {rd }}$ and $6^{\text {th }}$ grades. The estimates imply that extending choice to all students in the province would lead to gains in $6^{\text {th }}$ grade reading and mathematics scores on the order of $0.06-0.08$ of a standard deviation, with larger effects in fast-growing areas.

\section{Previous Research}

Our work builds on several strands of existing research on school competition, mostly focused on the U.S. ${ }^{5}$ One important antecedent is research on the role of private school competition in increasing public school performance. Couch et al. (1993) related district-wide test scores at public schools to the fraction of local students in private schools and interpreted the positive correlation as evidence of a competition effect. ${ }^{6}$ Hoxby (1994) noted that private school enrollment will vary with the quality of local public schools, causing an endogeneity bias in Couch et al.'s specification. Using the fraction of Catholics in a metropolitan area as an instrument for private enrollment, Hoxby obtained a positive effect on test outcomes. Subsequent instrumental variables (IV) studies (e.g., Arum, 1996, Jepsen, 2003) have found weaker effects, and an extensive re-analysis by Jepsen (2002) concludes that the effects of private school competition in the U.S. are probably small. Our research design is similar,

\footnotetext{
${ }^{5}$ See Belfield and Levin (2002) for a comprehensive review of studies of competition in public education in the U.S

${ }^{6}$ Subsequent studies using the same approach (Newmark, 1995; Sander, 1999; Geller et al. 2006) have found generally insignificant effects. An exception is Dee (1998), who estimates a positive effect on graduation rates.
} 
although in our setting Catholic schools are free and readily accessible in virtually all neighborhoods in the province. Moreover, they have the same resources per pupil as public schools, and follow the same curriculum. ${ }^{7}$ We conjecture that the competitive pressure posed by the separate school system (which educates over one-quarter of Ontario students) is greater than the pressure from private schools in the U.S. (which only educate $10 \%$ of students).

A second group of studies examines Tiebout competition between public school districts in the same geographic area. Borland and Howsen (1992) used the Herfindahl index of enrollment shares at different school districts as a measure of Tiebout competition and found a slightly negative effect on public school test scores. ${ }^{8}$ Arguing that district fragmentation is endogenous, Hoxby (2000) used the number of rivers and streams running through a metropolitan area as an instrument for the Herfindahl index and obtained positive competition effects. Re-analyzing these results, Rothstein (2006a) found smaller and generally insignificant effects from a range of alternative specifications. Rothstein (2006b) found little effect of district fragmentation on sorting between districts, suggesting that Tiebout competition is limited.

Direct evidence on voucher-based competition comes from a study of Chilean schools by Hsieh and Urquiola (2006). Using comparisons across different municipalities, they found no significant relationship between private school entry rates and district-wide gains in student outcomes. Consistent with theoretical analyses by Epple and Romano (1998) and Nechyba (2000), however, they find that the introduction of vouchers leads to increased stratification of SES-groups across schools.

\footnotetext{
${ }^{7}$ The Ministry of Education publishes detailed specifications for the performance expectations of students by grade in all subjects (see Ontario Ministry of Education, 2005). The standardized tests we use in this paper are designed to measure progress toward these objectives.

${ }^{8}$ In an interesting district-level analysis, Millimet and Rangaprasad (2006) test for strategic interactions between the input choices of nearby school districts in Illinois, and report positive and generally significant effects of nearby competitors' choices on a district's choices over pupil/teacher ratios, spending per pupil, and average school size.
} 
A third literature compares the test scores of students at private and public schools. Coleman, Hoffer and Kilgore (1982) documented that private school students in the U.S. (the majority of whom attend Catholic schools) have higher test scores than public school students. Cain and Goldberger (1982) cautioned that selectivity biases could account for this gap, and subsequent studies have used either Catholic religion, distance to a Catholic school, or the interaction of Catholic religion and distance to a Catholic school as instruments for private school choice (e.g., Evans and Schwab, 1995; Neal, 1997; Grogger and Neal, 2000; Figlio and Ludwig, 2000). Recently, Altonji, Elder, and Taber (2005b) have shown that all three of these instruments have a direct correlation with student graduation rates, potentially invalidating the IV design. As discussed below, our identification strategy relies on comparisons between areas with different fractions of Catholic families to identify cross-system competition effects. To address the concern raised by Altonji et al.'s findings, we focus on comparisons that vary the fraction of Catholics, while holding constant the fraction of groups other than Catholics and Protestants in an area. We establish that in our data and in the sample used by Altonji et al., Catholics and Protestants have very similar parental education and test score outcomes, though both have better outcomes than families with no religious affiliation.

\section{Institutional Detail and Conceptual Framework}

\section{a. Institutional Background}

Two parallel publicly-funded school systems have co-existed in Ontario since 1841. Originally both systems were financed by local property taxes, with ratepayers choosing which system to support. A provincial equalization system was introduced in the 1930s, and since 1985 the Ontario government has provided (roughly) equal funding for all elementary and secondary 
schools operated by the two systems. ${ }^{9}$ Today, Ontario public schools are secular and are legally required to accept all students, whereas separate schools restrict enrollment to children of Catholic backgrounds. ${ }^{10}$ The province is partitioned into overlapping grids of public and separate school "boards". As of 2003, there were 31 English speaking public school boards (with an average enrollment of 44,000) and 29 English speaking separate school boards (with an average enrollment of 18,000 ). There were also 23 "school authorities" that operated schools in remote rural areas, and a handful of French-language school boards. ${ }^{11}$

Teachers in the two systems are covered by collective bargaining agreements and are paid similar salaries. As noted above, both systems also follow the same standardized curriculum. School construction costs for both systems are financed by a provincial grant program that compares enrollment to capacity at the school board level. Effectively, the province operates two "public" school systems, one of which is only available to students with a Catholic background.

\section{b. A Simple Model of Enrollment Demand, School Quality, and Managerial Effort}

In this section we present a simple model of enrollment choice by Catholic families. We then consider a model of effort determination by the managers of adjacent public and separate schools, and show how local market characteristics - including the fraction of Catholic families in an area - would be expected to affect the efficiency of schools.

\footnotetext{
${ }^{9}$ The equalization system was replaced in 1998 with full provincial funding on a capitation basis.

${ }^{10}$ Separate schools have some discretion in setting the degree of "Catholicism" required for admission, but most limit enrollment to baptized Catholics, or the children of a baptized Catholic. Separate schools can also in principle deny admission to students for behavioral or other reasons.

${ }^{11}$ About $5 \%$ of students attend private schools that receive no public funding. We ignore these schools throughout this paper.
} 
Consider an area with $\mathrm{n}_{1}$ non-Catholic families and $\mathrm{n}_{2}$ Catholic families, each with one school-age child. Assume there are only two schools in the area: a public school with quality $\mathrm{Q}_{\mathrm{p}}$ and a separate school with quality $\mathrm{Q}_{\mathrm{s}}$. (We discuss the case of multiple schools below). Catholic family $i$ associates payoffs $U_{i p}$ and $U_{\text {is }}$ to the choices of the public and separate school, respectively, where

(1a) $\quad \mathrm{U}_{\mathrm{ip}}=\alpha_{\mathrm{ip}}+\beta \mathrm{Q}_{\mathrm{p}}-\gamma \mathrm{t}_{\mathrm{ip}}+\varepsilon_{\mathrm{ip}}$

$$
\mathrm{U}_{\mathrm{is}}=\alpha_{\mathrm{is}}+\beta \mathrm{Q}_{\mathrm{s}}-\gamma \mathrm{t}_{\mathrm{is}}+\varepsilon_{\mathrm{is}} .
$$

Here, $\alpha_{\mathrm{ip}}$ and $\alpha_{\mathrm{is}}$ represent family-specific valuations associated with the choices, $\mathrm{t}_{\mathrm{ip}}$ and $\mathrm{t}_{\mathrm{is}}$ are the travel costs to the schools, and $\left(\varepsilon_{\mathrm{ip},} \varepsilon_{\mathrm{is}}\right)$ is a pair of random shocks assumed to be independently and identically distributed across the population. ${ }^{12}$ Conditional on $\left(\alpha_{\mathrm{ip}}, \alpha_{\mathrm{is}}, \mathrm{Q}_{\mathrm{p}}, \mathrm{Q}_{\mathrm{s}}, \mathrm{t}_{\mathrm{ip}}, \mathrm{t}_{\mathrm{is}}\right)$, the probability that family i selects the public school is

$$
\mathrm{F}\left[\delta_{\mathrm{i}}+\beta \Delta \mathrm{Q}-\gamma \Delta \mathrm{t}_{\mathrm{i}}\right]
$$

where $\mathrm{F}$ is the distribution function of the random variable $\mathrm{v}_{\mathrm{i}}=\varepsilon_{\mathrm{ip}}-\varepsilon_{\mathrm{is}}, \delta_{\mathrm{i}}=\alpha_{\mathrm{ip}}-\alpha_{\mathrm{is}}$ is a familyspecific relative taste for public schools, $\Delta \mathrm{Q}$ is the quality gap between the schools, and $\Delta \mathrm{t}_{\mathrm{i}}$ is the difference in travel costs to the two schools.

Assume that the area can be divided into a set of neighborhoods $\mathrm{k}=1,2 \ldots \mathrm{K}$, and that all families in neighborhood $\mathrm{k}$ have the same travel cost differential $\Delta \mathrm{t}_{\mathrm{k}}$. The share of Catholic families in neighborhood $\mathrm{k}$ who choose a public school is

$$
\mathrm{s}_{\mathrm{k}}\left(\Delta \mathrm{Q}, \Delta \mathrm{t}_{\mathrm{k}}\right)=\int \mathrm{F}\left[\delta_{\mathrm{i}}+\beta \Delta \mathrm{Q}-\gamma \Delta \mathrm{t}_{\mathrm{k}}\right] \mathrm{h}\left(\delta_{\mathrm{i}} \mid \mathrm{k}\right) \mathrm{d} \delta_{\mathrm{i}},
$$

\footnotetext{
${ }^{12}$ A similar "random utility" formulation is widely used in models of demand for differentiated products. See Nevo (2000) for discussion and references, and Hastings, Kane and Staiger (2006) for an application to school choice.
} 
where $\mathrm{h}\left(\delta_{\mathrm{i}} \mid \mathrm{k}\right)$ represents the density of relative tastes among Catholic families in the neighborhood. ${ }^{13}$ Letting $\mathrm{n}_{2 \mathrm{k}}$ represent the number of Catholic families in neighborhood $\mathrm{k}$, the total fraction of Catholics who choose the public school is

$$
\mathrm{s}(\Delta \mathrm{Q}) \equiv \sum_{\mathrm{k}} \mathrm{n}_{2 \mathrm{k}} / \mathrm{n}_{2} \times \mathrm{s}_{\mathrm{k}}\left(\Delta \mathrm{Q}, \Delta \mathrm{t}_{\mathrm{k}}\right)
$$

Public and separate school enrollments are therefore given by

(3a) $\quad \mathrm{E}_{\mathrm{p}}=\mathrm{n}_{1}+\mathrm{n}_{2} \mathrm{~s}(\Delta \mathrm{Q})$,

(3b) $\quad \mathrm{E}_{\mathrm{s}}=\mathrm{n}_{2}[1-\mathrm{s}(\Delta \mathrm{Q})]$.

The responsiveness of enrollment in either system to the quality gap between schools is:

$$
\begin{aligned}
\partial \mathrm{E}_{\mathrm{p}} / \partial \Delta \mathrm{Q} & =-\partial \mathrm{E}_{\mathrm{s}} / \partial \Delta \mathrm{Q}=\mathrm{n}_{2} \mathrm{~s}^{\prime}(\Delta \mathrm{Q}) \\
& =\mathrm{n}_{2} \sum_{\mathrm{k}} \quad \mathrm{n}_{2 \mathrm{k}} / \mathrm{n}_{2} \partial \mathrm{s}_{\mathrm{k}}\left(\Delta \mathrm{Q}, \Delta \mathrm{t}_{\mathrm{k}}\right) / \partial \Delta \mathrm{Q},
\end{aligned}
$$

where

$$
\partial \mathrm{s}_{\mathrm{k}}\left(\Delta \mathrm{Q}, \Delta \mathrm{t}_{\mathrm{k}}\right) / \partial \Delta \mathrm{Q}=\beta \int \mathrm{f}\left[\delta_{\mathrm{i}}+\beta \Delta \mathrm{Q}-\gamma \Delta \mathrm{t}_{\mathrm{k}}\right] \mathrm{h}\left(\delta_{\mathrm{i}} \mid \mathrm{k}\right) \mathrm{d} \delta_{\mathrm{i}},
$$

and $\mathrm{f}\left[\mathrm{]}\right.$ is the density associated with $\mathrm{F}\left[\mathrm{]}\right.$. The magnitude of $\partial \mathrm{s}_{\mathrm{k}} / \partial \Delta \mathrm{Q}$ depends on the degree of taste heterogeneity among Catholic families. ${ }^{14}$ If, at one extreme, the population consists of only two types - those who always choose public schools $\left(\delta_{\mathrm{i}}=\infty\right)$ and those who never do $\left(\delta_{\mathrm{i}}=\infty\right)-$ then $\partial \mathrm{s}_{\mathrm{k}} / \partial \Delta \mathrm{Q}=0$. If, on the other hand, $\delta_{\mathrm{i}}=\delta$, then all the Catholic families make the same choice and $\mathrm{s}_{\mathrm{k}}(\Delta \mathrm{Q})$ is a step function. We assume that $\mathrm{h}\left(\delta_{\mathrm{i}} \mid \mathrm{k}\right)$ lies between these two extremes, and is strictly positive on $(-\infty, \infty)$.

Assume that school quality is an increasing concave function of the level of effort (e) exerted by school managers:

$$
\mathrm{Q}_{\ell}=\mathrm{q}\left(\mathrm{e}_{\ell}\right) \text {, for } \ell=\{\mathrm{s}, \mathrm{p}\} \text {, }
$$

\footnotetext{
${ }^{13}$ As an example, suppose $\delta_{\mathrm{i}}$ is normally distributed with mean $\delta_{\mathrm{k}}$ and variance $\sigma^{2}$ in neighborhood $\mathrm{k}$. Then $\mathrm{S}_{\mathrm{k}}=\int \sigma^{-1} \mathrm{~F}\left[\sigma \cdot \mathrm{z}+\delta_{\mathrm{k}}+\beta \Delta \mathrm{Q}-\gamma \Delta \mathrm{t}_{\mathrm{k}}\right] \varphi(\mathrm{z}) \mathrm{dz}$ where $\varphi(\mathrm{z})$ is the standard normal density.

${ }^{14}$ More generally, the coefficient $\beta$ may vary across families. In this case, $\partial \mathrm{s}_{\mathrm{k}} / \partial \Delta \mathrm{Q}=\iint \beta_{\mathrm{i}} \mathrm{f}\left[\delta_{\mathrm{i}}+\beta_{\mathrm{i}} \Delta \mathrm{Q}-\gamma \Delta \mathrm{t}_{\mathrm{k}}\right] \mathrm{h}\left(\beta_{\mathrm{i}}, \delta_{\mathrm{i}} \mid \mathrm{k}\right) \mathrm{d} \beta_{\mathrm{i}} \mathrm{d} \delta_{\mathrm{i}}$ where $\mathrm{h}\left(\beta_{\mathrm{i}}, \delta_{\mathrm{i}} \mid \mathrm{k}\right)$ is the joint distribution of $\left(\beta_{\mathrm{i}}, \delta_{\mathrm{i}}\right)$ in area $\mathrm{k}$.
} 
and that the preferences of each manager are represented by a linear function of effort and the share of local students attending his or her school:

$$
\mathrm{U}_{\ell}\left(\mathrm{E}_{\ell}, \mathrm{e}_{\ell}\right)=\theta \mathrm{E}_{\ell} / \mathrm{n}-\mathrm{e}_{\ell},
$$

where $\theta>0$ reflects the relative weight on market share. ${ }^{15}$ The first order conditions for optimal effort choices are:

$$
\begin{aligned}
& \theta\left(\mathrm{n}_{2} / \mathrm{n}\right) \mathrm{s}^{\prime}(\Delta \mathrm{Q}) \mathrm{q}^{\prime}\left(\mathrm{e}_{\mathrm{p}}\right)-1=0 \\
& \theta\left(\mathrm{n}_{2} / \mathrm{n}\right) \mathrm{s}^{\prime}(\Delta \mathrm{Q}) \mathrm{q}^{\prime}\left(\mathrm{e}_{\mathrm{s}}\right)-1=0
\end{aligned}
$$

In equilibrium both managers supply the same level of effort $\mathrm{e}^{*}$, with

$$
\mathrm{q}^{\prime}\left(\mathrm{e}^{*}\right)=1 /\left[\theta\left(\mathrm{n}_{2} / \mathrm{n}\right) \mathrm{s}^{\prime}(0)\right] \text {. }
$$

Since $\mathrm{q}^{\prime}(\mathrm{e})$ is decreasing in e, equilibrium effort is increasing in $\left(\mathrm{n}_{2} / \mathrm{n}\right) \mathrm{s}^{\prime}(0)$, the derivative of market share with respect to the quality gap, evaluated at $\Delta \mathrm{Q}=0$. In particular, since only Catholic families have choice, equilibrium effort varies with the local fraction of Catholics, and on the willingness of local Catholic families to consider switching systems to access higher quality schools.

\section{c. Assessing the Sensitivity of Enrollment Demand to Relative Quality}

In the absence of direct information on school quality it is difficult to measure the reaction of market shares to relative quality. Assuming enrollment choice is generated by a random utility model, however, useful insights can be gained by studying the change in enrollment at a given school when the competing system opens or closes a nearby school. The

\footnotetext{
${ }^{15}$ Equivalently one could assume that managers are rewarded for the number of students they attract. Friedman's (1955) original voucher proposal was predicated on the idea that managers receive a payoff proportional to the number of students they attract.
} 
reason is that local demand responses to variation in quality and travel distance are both governed by heterogeneity in tastes for a religious versus secular education. ${ }^{16}$

For example, suppose that a new separate school is opened with the same quality as the existing separate school. The predicted change in enrollment at the public school is:

$$
\partial \mathrm{E}_{\mathrm{p}} / \partial \text { Open }_{\mathrm{s}}=\mathrm{n}_{2} \sum_{\mathrm{k}}\left(\mathrm{n}_{2 \mathrm{k}} / \mathrm{n}_{2}\right) \partial \mathrm{s}_{\mathrm{k}}\left(\Delta \mathrm{Q}, \Delta \mathrm{t}_{\mathrm{k}}\right) / \partial \Delta \mathrm{t}_{\mathrm{k}} \times \partial \Delta \mathrm{t}_{\mathrm{k}} / \partial \operatorname{Open}_{\mathrm{s}}
$$

where $\partial \Delta \mathrm{t}_{\mathrm{k}} / \partial \mathrm{Open}_{\mathrm{s}}$ represents the relative change in travel costs in neighborhood $\mathrm{k}$ to attend a public versus separate school. ${ }^{17}$ In neighborhoods that are closer to the new separate school than the old one this expression is negative, leading some families to switch systems. From equation (2), however, the responses to change in travel costs and quality are proportional:

$$
\partial \mathrm{s}_{\mathrm{k}}\left(\Delta \mathrm{Q}, \Delta \mathrm{t}_{\mathrm{k}}\right) / \partial \Delta \mathrm{t}_{\mathrm{k}}=-\gamma / \beta \partial \mathrm{s}_{\mathrm{k}}\left(\Delta \mathrm{Q}, \Delta \mathrm{t}_{\mathrm{k}}\right) / \partial \Delta \mathrm{Q}
$$

Thus, the enrollment loss when a nearby school is opened can be expressed as a weighted sum of the derivatives of the market shares in each neighborhood with respect to quality:

$$
\partial \mathrm{E}_{\mathrm{p}} / \partial \text { Open }_{\mathrm{s}}=-\gamma / \beta \quad \mathrm{n}_{2} \sum_{\mathrm{k}}\left(\mathrm{n}_{2 \mathrm{k}} / \mathrm{n}_{2}\right) \partial \mathrm{s}_{\mathrm{k}}\left(\Delta \mathrm{Q}, \Delta \mathrm{t}_{\mathrm{k}}\right) / \partial \Delta \mathrm{Q} \times \partial \Delta \mathrm{t}_{\mathrm{k}} / \partial \operatorname{Open}_{\mathrm{s}},
$$

where the weight, $\partial \Delta \mathrm{t}_{\mathrm{k}} / \partial \mathrm{Open}_{\mathrm{s}}$, depends on the change in relative travel costs experienced by families in each neighborhood. Assuming that the travel cost changes are a function of local geography and don't covary with the distribution of tastes, we can use differences in the observed changes in enrollment following nearby openings by the competing system to infer the relative sensitivity of enrollment demand to quality. In particular, neighborhood characteristics that are associated with bigger enrollment losses when a competing school is opened nearby would be expected to generate more elastic enrollment demand with respect to quality, leading to more intensive effort competition.

\footnotetext{
${ }^{16}$ A similar idea is used by Bucklin, Russell, and Srinivasan (1998) to show that the cross-price elasticity of market shares for competing brands is proportional to the probabilities of switching between brands.

${ }^{17}$ For simplicity we are assuming that the changes in travel times $d \Delta \mathrm{t}_{\mathrm{k}}$ are small enough that the change in $\int \mathrm{F}\left[\delta_{\mathrm{i}}+\beta \Delta \mathrm{Q}-\gamma \Delta \mathrm{t}_{\mathrm{k}}\right] \mathrm{h}\left(\delta_{\mathrm{i}} \mid \mathrm{k}\right) \mathrm{d} \delta_{\mathrm{i}}$ can be approximated by $-\gamma d \Delta \mathrm{t}_{\mathrm{k}} \int \mathrm{f}\left[\delta_{\mathrm{i}}+\beta \Delta \mathrm{Q}-\gamma \Delta \mathrm{t}_{\mathrm{k}}\right] \mathrm{h}\left(\delta_{\mathrm{i}} \mid \mathrm{k}\right) \mathrm{d} \delta_{\mathrm{i}}=-\gamma d \Delta \mathrm{t}_{\mathrm{k}} \partial \mathrm{s}_{\mathrm{k}} / \partial \Delta \mathrm{t}_{\mathrm{k}}$.
} 


\section{d. Extension and Implementation}

Contrary to our simplified model, the public and separate systems operate multiple schools. Since both systems use attendance zones to assign neighborhoods to specific schools, each family's choice problem is the same as in the simplified two-school case. The effort-setting game is more complicated, however, because in general each school manager competes with multiple managers in the opposing system. Nevertheless, as we show in Appendix 1, the equilibrium has the same qualitative properties as in the two-school case. In particular, the incentives for effort depend on the local fraction of Catholic students, and on the degree of taste heterogeneity among Catholic families for a secular versus Catholic education. These same characteristics also affect the magnitude of the enrollment losses experienced by an existing school when the competing system opens a new school nearby. In the next section we use this insight to develop measures of the cross-system competitive pressure in different geographic areas.

\section{Enrollment Responses to Nearby Openings and Closings}

\section{a. Identification of Openings, Closings, and Affected Schools}

We obtained a file from the Province of Ontario with information on annual enrollments by grade at all publicly-funded schools between 1990 and 2004. Using this file, we define a newly opened elementary school as one that has positive enrollment in grades 2-4 in a given year (the "opening year") and zero total enrollment in all previous years. ${ }^{18}$ Similarly, we define a recently closed elementary school as one with positive enrollment in grades 2-4 in a given year

\footnotetext{
${ }^{18}$ We include "French Immersion" schools as they are offered by the English language school boards. During the 1990s there were roughly 2300 public elementary schools and 1100 separate schools in operation in a year.
} 
and zero enrollment in the next year (the "closing year") and all subsequent years. ${ }^{19}$ Further information is provided in Appendix 2.

Panel A of Table 1 presents some descriptive information on the opening and closing of elementary schools operated by English language school boards. Over the 15 years of our sample period there were 252 openings and 212 closings in the public system and 169 openings and 102 closings in the separate school system. As shown in the second column of the panel, a disproportionate share of the events occurred in the second half of our sample period, reflecting a major consolidation of school boards in 1998. Geographically, elementary school openings are concentrated in the rapidly growing ring of cities and suburbs around Toronto, while closings are concentrated in slower growing rural areas and the inner-city areas of Toronto. We matched schools to Census information tabulated at the neighborhood level (defined by the first three characters of the school's postal code) to compare neighborhoods with openings and closings. A key difference is in the fraction of houses built in the neighborhood between 1991 and 2001, which averages $33 \%$ for neighborhoods where there were only school openings versus $6 \%$ in neighborhoods with only school closings. ${ }^{20}$

Our next step is to identify existing schools that were potentially impacted by nearby openings and/or closings. For simplicity, we restrict attention to non-rural affected schools. We started by including all existing schools in a circle around the newly opened or closed school, with radius equal to the average travel distance from home to school for students at nearby

\footnotetext{
${ }^{19}$ Schools are sometimes paired together for administrative purposes. When this occurs both schools are listed as in operation, though enrollment is only reported at one of the schools. We identified "pairing events" and verified their status with information from the Ministry of Education. They are not counted as openings or closings.

${ }^{20}$ See Appendix Table 1. There is also some variation in income and family structure. Neighborhoods with only openings have the highest average income and lowest fraction of single parents, whereas those with only closings have the lowest family incomes and the most single parents. Differences in religious affiliation, education, and family size are smaller, although the fraction of immigrants tends to be lower in areas with both openings and closings than in other areas, as does the fraction of Catholics.
} 
elementary schools (typically around 1 kilometer). ${ }^{21}$ We then used satellite images and maps to eliminate schools that were separated from the newly opened or closed school by a major travel barrier (e.g., a controlled-access highway) - see Appendix 3. We have checked the sensitivity of our results to the inclusion of these "rejected" schools and find similar (though typically weaker) evidence of cross-system enrollment flows when they are included. ${ }^{22}$

The third column in Panel A of Table 1 reports the share of opening and closing events for which we were able to identify at least one non-rural affected school. This ranges from 45 to 75 percent. In columns 4 and 5, we report the means and standard deviations of total enrollment (for grades 1-6) at the opened and closed schools, classified by whether we can identify at least one affected non-rural school. Typically, a newly opened school has about 320 students in the period after opening, while closing schools are smaller.

Panel B of Table 1 shows the number of affected schools associated with various opening/closing events, and the average distance between the opening/closing school and the affected school(s). Affected schools operated by the competing systems tend to be relatively close to the opening/closing schools, suggesting that the opening and closing events have the potential to induce at least some students to move between the rival systems.

Panel C of Table 1 shows the distribution of the number of affected schools for each type of opening or closing event. On average, a school opening affects 2.6 nearby schools, whereas a closing affects 3.6 nearby schools. The smaller number for openings reflects their concentration in growing suburban areas with a relatively low density of existing schools. Closing schools, by comparison, tend to be situated in older neighborhoods where schools are closer together. The

\footnotetext{
${ }^{21}$ We obtained information for one year on the postal codes of all students attending each elementary school in the province. We use the centroids of the postal codes for the schools and the homes to compute travel distances.

${ }^{22}$ We also created a data set that included only the schools near an opening or closing that are excluded from the main analysis sample. The estimated effects of openings and closings on these "excluded" schools are small and statistically insignificant.
} 
relatively smaller size of closing schools (Panel A) and the fact that each closing affects a larger number of nearby schools suggests that the impact per affected school may be smaller than the impact of openings.

\section{b. Effects of Nearby Openings and Closings on Enrollment}

Our third step is to estimate the effect of nearby openings and closings on affected schools. Of the roughly 2,600 non-rural elementary schools in the province that were in operation for at least two years between 1990 and 2004, 945 were affected by at least one opening or closing event and have enrollment data from both before and after the event. ${ }^{23}$ Using this sample we estimate enrollment models of the form:

$$
\Delta \mathrm{E}_{\mathrm{sat}}=\mathrm{X}_{\mathrm{sat}} \mathrm{b}+\sum_{\mathrm{j}=1}^{4} \text { Event }_{\mathrm{jst}} \times\left\{\mathrm{D}_{\mathrm{s}} \mathrm{d}_{\mathrm{j}-\mathrm{pub}}+\left(1-\mathrm{D}_{\mathrm{s}}\right) \mathrm{d}_{\mathrm{j}-\mathrm{sep}}\right\}+\mathrm{\alpha}_{\mathrm{s}}+\omega_{\mathrm{t}}+\mathrm{e}_{\mathrm{sat}},
$$

where $\Delta \mathrm{E}_{\text {sat }}$ is a measure of enrollment growth at school s in area a in year $\mathrm{t} ; \mathrm{X}_{\text {sat }}$ is a vector of time-varying school and area characteristics; Event $\mathrm{j}_{\mathrm{jst}}$ is a set of dummies for recent opening/closing events at nearby schools that affect this school in year $t, D_{s}$ is a dummy for a public school, $\alpha_{s}$ is a school fixed effect, $\omega_{t}$ is a period fixed effect, and $e_{\text {sat }}$ represents an error term. We identify four types of events -- public openings, separate openings, public closings, and separate closings -- and allow separate coefficients $\left(\mathrm{d}_{\mathrm{j}-\mathrm{pub}}\right.$ and $\left.\mathrm{d}_{\mathrm{j} \text {-sep }}\right)$ for the effect of each event type on nearby public and separate schools. Note that the models include school fixed effects. Thus, the coefficients measure gains or losses in enrollment in the period following an opening or closing event, allowing for school-specific enrollment trends.

\footnotetext{
${ }^{23}$ We exclude middle schools that never had any enrollment below $6^{\text {th }}$ grade during the sample period. Combined schools that have both grades 1-6 and 7-8 are included in our final sample in any year that they have grades 1 to 6 . A cross-classification of affected schools by the number of "affecting events" (i.e. nearby openings and closings) is presented in Appendix Table 2. Two-thirds were affected by only one event, and another quarter was affected by exactly two events. Only about $10 \%$ were affected by three or more opening/closing events.
} 
Our primary measure of enrollment growth is the percentage change in enrollment from grades $1-5$ in the previous year to grades $2-6$ in the current year. ${ }^{24}$ This measure captures any systematic losses or gains in enrollment among students who are already attending the school. As an alternative we use the change in grade 1 enrollment from the previous year to the current year. This measure is somewhat noisier than the average change in continuing enrollment, reflecting fluctuations in the size of the grade 1 entry cohort. On the other hand, to the extent that parents make a "once for all" school choice when their children enter school, the growth in first grade enrollment may be more sensitive to changes in the availability of alternative schools.

Table 2 presents the means and standard deviations of these two measures. The first row also shows average first-grade enrollments. A typical public school in our sample has about 50 first grade students (and similar enrollments at higher grades), while a typical separate school is a little smaller (44 students). Between consecutive years grade 1 enrollment rises at an average rate of $1.9 \%$ in the public schools and $2.4 \%$ in separate schools. Growth rates vary substantially across schools, with a standard deviation of $26 \%$ for the public schools and $31 \%$ for the separate schools. Average enrollment growth from grades 1-5 to grades 2-6 is smaller (under $1 \%$ at both public and separate schools), and less variable.

As explanatory variables in our enrollment growth models we include an indicator for whether the school is paired with another school for administrative purposes and a set of neighborhood-level characteristics. ${ }^{25}$ The latter are based on linear interpolations of neighborhood-level Census tabulations from the 1991, 1996, 2001, and 2006 Censuses, and

\footnotetext{
${ }^{24}$ Our school level database includes enrollment by grade for each school, as well as the enrollment of ungraded students in special education and other programs. We allocated these students uniformly across all grades offered by the school. For schools that do not offer all grades from 1 to 6 , we modify the enrollment measure to reflect only those grades for which the school consistently has enrollment.

${ }^{25} \mathrm{We}$ have explored specifications that also include whether the school has recently opened (within the last 6 years). The results are similar to those reported in this paper.
} 
include the shares of the population aged 5-9 and 10-14, the share of recently constructed houses, and various demographic characteristics, including the fractions of residents who are Catholic, and in different immigrant groups. ${ }^{26}$ In addition we use our enrollment database to estimate the fractions of children enrolled in public Francophone schools and private schools.

A key issue for the specification of equation (9) is the lag structure between opening/closing events and subsequent enrollment changes at nearby schools. This is particularly important for openings, since new schools often open at reduced capacity and expand slowly as facilities are completed. We investigated this by allowing the dummies for nearby events to "turn on" for different lengths of time, and by considering specifications in which nearby events cause a permanent shift in the growth rate of enrollment (i.e., the dummies remain on indefinitely). The results showed that the effects of openings and closings on schools in the same system emerge quickly, whereas the effects on schools in the competing system take at least 3 years to stabilize. We therefore "turn on" the indicators for nearby events in each of the three years following an event, and assume no impact before and after. Our key findings are similar if we allow 4 or 5 year impacts.

Table 3 shows the estimated effects of school openings on enrollment changes at nearby schools in the same and the opposing system from alternative specifications of equation (9). All of the models also include the effect of nearby closings. As discussed in more detail below, however, the cross-system effects of closings are never large, and in the interest of space we report the coefficients for the closing effects in Appendix Table 3.

\footnotetext{
${ }^{26}$ Measures on religion were only collected in the 1991 and 2001 Censuses. Neighborhood tabulations are available by so-called "Forward Sortation Area" (FSA) which is based on the first 3 characters of the postal code, and has a typical population of about 5,000 households. In assigning FSA characteristics to schools, we use boundaries as of 1996, and link FSA's across Census years using information provided by Statistics Canada. 1991 data are unavailable for a few FSAs: in these cases we use data for 1996 to assign information to the period from 1990 to 1996. Across 1996, 2001, 2006 there are a few FSAs that have suppressed information for one or more of the censuses. For these FSAs we used the values of measures for the closest FSA with consistent information across all FSAs. Summary statistics on the census measures are provided in Appendix Table 1.
} 
Columns 1 and 2 present models that include simple dummy variables for nearby openings and closings. The model in column1 is fit to changes in grade 1 enrollment, while the model in column 2 is fit to changes in continuing enrollment between grades 1-5 and 2-6. The coefficients in column 1 suggest that nearby openings lead to first grade enrollment reductions of $8-9 \%$ per year at nearby schools in the same system in each of the three years after the event (i.e., a cumulative impact of about $25 \%$ ). More important from our perspective are the cross-system effects, which are also negative, but about one-third as large. In particular, we estimate that grade 1 enrollment is reduced by $2-3 \%$ in each of the following 3 years (or a 6-9\% cumulative loss) when a nearby school is opened by the competing system. The opening effects using the continuing-cohort enrollment change measure (column 2) are similar, although the cross-system effects are a little smaller than for grade 1 students, potentially reflecting the "stickiness" of system choice once a student has started school.

Although not reported in the table, the estimated closing effects from the specifications in columns 1 and 2 imply that enrollment rises by 13-20\% over the next three years when a nearby school in the same system closes. Unlike openings, however, closings seem to have no effect on enrollment at nearby schools in the competing system. One explanation for this is that parents prefer new schools. In this case, more students will switch systems in response to an opening (to access a new school) than to a closing. To test this explanation we estimated the cross-system responses to nearby openings, allowing different impacts at newer schools (less than 5 years old) and older schools. Contrary to our initial expectations the estimates showed somewhat larger losses at relatively new schools.

An alternative explanation is that Catholic families in relatively new neighborhoods where social groups are still in flux, and few families have a connection to existing schools - are 
most likely to consider switching between systems. Since openings are concentrated in fastgrowing areas with a higher fraction of new residents, whereas closings are concentrated in urban neighborhoods with fewer recent arrivals, the cross-system response of enrollment growth to nearby openings will be relatively large, while the cross-system response to closings will be small. ${ }^{27}$ This hypothesis also explains the tendency for bigger cross-system enrollment losses at relatively new schools, since these tend to be located in fast-growing areas.

To test this explanation we fit a model that allows the effect of nearby openings to vary with a simple proxy for the newness of the neighborhood - the growth rate of the housing stock over the 1990s, as measured by the fraction of units in 2001 that were built after $1991{ }^{28}$ The results are presented in column 3 of Table $3{ }^{29}$ The interaction coefficients show that nearby openings have larger (i.e., more negative) own-system effects in areas with faster population growth, particularly for the public system. ${ }^{30}$ The cross-system opening interactions are also strongly negative, suggesting that Catholic parents in fast-growing neighborhoods are more willing to switch systems when the rival system opens a nearby school. Interestingly, the implied responses in slow-growth areas are essentially zero -comparable to the cross-system enrollment flows following school closings.

Since only Catholic students can switch between school systems, the cross-system enrollment losses from nearby openings should also vary with the fraction of Catholics in the

\footnotetext{
27 An extreme version of this argument is that only newly arriving families consider switching systems.

${ }^{28} \mathrm{We}$ have also used an alternative based on local population growth. This yields qualitatively similar but somewhat less precise estimates for the models presented below.

${ }^{29}$ Note that the estimated models in Table 4 include reactions to nearby closings, though for simplicity these are not reported in the table.

${ }^{30}$ The mean of the new housing share variable is 0.17 , with a range between 0.01 and 0.98 , and a standard deviation of 0.18 . Moreover, the mean new housing share in neighborhoods with school openings about 5 times bigger than in neighborhoods with school closings. Thus, the own-system effect of a public opening roughly doubles in magnitude as the growth rate of the neighborhood rises from 0 to the mean value.
} 
local area. ${ }^{31}$ To test this we include interactions of the cross-system opening indicators with the fraction of Catholics in the Forward Sortation Area (FSA) in which the school is located. Results for four versions of this specification are reported in columns 4-7 of Table 3.

The specification in column 4 includes both the main effects of cross-system openings, and their interactions with the local fraction of Catholics. Judging by the sampling errors of the estimates from this model we do not have enough power to separately identify the main opening effects and the interaction terms. To improve precision, we fit the restricted model reported in column 5 that excludes the main effects. This specification imposes the prediction of our theoretical model that the opening responses are proportional to the fraction of Catholics in the area, and fits as well as the less restrictive model. The magnitudes of the coefficients suggest that in very-high Catholic areas, the cross-system reactions to nearby openings are relatively large - on the order of one-half the magnitude of the own-system responses.

The model in column 6 of Table 3 allows the cross effects to vary with both the local Catholic share and the growth rate of the local housing stock. Echoing the results in column 3, the triple interaction terms (in rows 8 and 12) are large in magnitude and statistically significant, whereas the two-way interactions of the Catholic share with the opening indicator (in rows 7 and 11) are small. Our final specification in column 7 therefore drops the Catholic interactions and includes only the triple interactions of Opening $\times$ Catholic Share $\times$ Share of New Housing. This model fits as well as the preceding one, and implies that in a neighborhood with a growth rate of 0.33 (the mean for neighborhoods with only openings) and a $40 \%$ Catholic share, the opening of a new school by the competing system leads to cumulative enrollment losses of 4-11 percent at nearby existing schools. In areas with a greater share of Catholics or faster population growth,

\footnotetext{
${ }^{31}$ Strictly speaking this is only true if the distribution of preferences for secular versus Catholic education among Catholic families does not vary with the local fraction of Catholics.
} 
the reactions are bigger, whereas in areas with few Catholics, or negligible growth, the reactions are essentially 0 . Holding constant area characteristics, the measured cross-system enrollment responses to a nearby opening are larger at public schools than separate schools, although we cannot reject equality at conventional significance levels.

\section{Impacts of Competition on Student Achievement}

\section{a. Modeling the Effect of Effort Competition on Student Achievement}

The second step in our empirical analysis is to relate the degree of competition between systems to the academic achievement of students. Our achievement measures are based on standardized tests written by students in the $3^{\text {rd }}$ and $6^{\text {th }}$ grades. Building on the existing education production function literature (e.g., Rivkin, Hanushek, and Kain, 2005) we assume that the test score of student $\mathrm{i}$ in grade $\mathrm{g} 0\{3,6\}$ who attends school $\mathrm{s}$ in area a depends on his or her observed characteristics $\mathrm{X}_{\text {isa }}$, on school characteristics $\mathrm{Z}_{\mathrm{sa}}$ (including an indicator for whether the school is public or separate), on the characteristics of the local area $\mathrm{W}_{\mathrm{a}}$, on a measure of crosssystem competitive pressure in the area, $\mathrm{I}_{\mathrm{a}}$, and on unobserved ability and random factors $\mathrm{e}_{\text {gisa: }}$ :

$$
\mathrm{T}_{\text {gisa }}=\mathrm{X}_{\text {gisa }} \mathrm{b}_{\mathrm{gx}}+\mathrm{Z}_{\mathrm{sa}} \mathrm{b}_{\mathrm{gz}}+\mathrm{W}_{\mathrm{a}} \mathrm{b}_{\mathrm{gw}}+\mathrm{I}_{\mathrm{a}} \mathrm{b}_{\mathrm{gI}}+\mathrm{e}_{\text {gisa }} .
$$

Note that in this specification local competitive pressure is a "market" characteristic that affects the achievement of all students - not just those who attend a specific school or subset of schools. Note too that the coefficients in equation (10) are all grade-specific. In particular, assuming that learning depends on the duration of exposure to the school environment, and that competitive pressure leads to a better environment, we expect that $b_{61}>b_{3 I}$.

Because of neighborhood sorting, unobserved student abilities are likely to be correlated with school and neighborhood characteristics, leading to biases in OLS estimation of (10). When 
longitudinal student data are available the conventional solution is to estimate the model in first differences (e.g., Rivkin, Hanushek, and Kain, 2005). Since we cannot link $3^{\text {rd }}$ and $6^{\text {th }}$ grade test takers in our data base, we follow an alternative approach of including school $\times$ cohort fixed effects and entering the time-invariant school and neighborhood variables as interactions with an indicator for test takers in $6^{\text {th }}$ grade $\left(\mathrm{Gr} 6_{\mathrm{ig}}\right)$ :

$$
\mathrm{T}_{\text {gisa }}=\mathrm{X}_{\text {gisa }} b_{\mathrm{gx}}+\mathrm{Z}_{\mathrm{sa}} \mathrm{Gr} 6_{\mathrm{ig}} \mathrm{b}_{\mathrm{z}}+\mathrm{W}_{\mathrm{a}} \mathrm{Gr} 6_{\mathrm{ig}} \mathrm{b}_{\mathrm{w}}+\mathrm{I}_{\mathrm{a}} \mathrm{Gr} 6_{\mathrm{ig}} \mathrm{b}_{\mathrm{I}}+\xi_{\text {coh(i),s}}+\mathrm{e}_{\text {gisa }}^{\prime}
$$

In this specification $\xi_{\operatorname{coh}(i), s}$ represents a fixed effect for the cohort of students who were in third grade at school $\mathrm{s}$ at the same time as student $\mathrm{i}$ (or in $6^{\text {th }}$ grade at the same school 3 years later), and $\mathrm{e}_{\text {gisa }}^{\prime}$ represents the unexplained component of student i's score in grade g. In the presence of cohort $\times$ school fixed effects, we can only identify the differential (or "value-added") effects of the time-invariant variables. Thus, the coefficient on the competitive index is $b_{\mathrm{I}}=\mathrm{b}_{6 \mathrm{I}}-\mathrm{b}_{3 \mathrm{I}}$, with similar expressions for $b_{z}$ and $b_{w}$.

If all students remain at the same school between $3^{\text {rd }}$ and $6^{\text {th }}$ grades, estimates based on this approach are numerically identical to those from a model of test score gains between $3^{\text {rd }}$ and $6^{\text {th }}$ grades. $^{32}$ In the presence of student mobility, however, the two approaches will yield different estimates. For consistent estimation of the value-added coefficients using (11), any difference in average abilities between the leavers and joiners at a school must be uncorrelated with the observed covariates. ${ }^{33}$ We maintain this assumption throughout our analysis.

A second key assumption is that our measures of competitive pressure are orthogonal to unobserved determinants of achievement growth. Based on the analysis in Table 3 we use two measures of local competitive pressure. The first is just the fraction of Catholic families in an area. The second is the product of the local fraction of Catholics and the growth rate of the local

\footnotetext{
32 This assumes that the first differenced specification includes grade-specific coefficients for the time-varying individual X's.

${ }^{33}$ A differenced model, by comparison, requires that school leavers are as good as randomly selected.
} 
area. Since we do not observe the religion of individual test takers, either of these choices poses a potential problem if Catholic children have systematically different test score gains than other students. We study this issue in detail in subsection c., below.

\section{b. Test Score Data}

In 1998 Ontario introduced province-wide testing for all students in publicly funded schools in grades 3,6 , and 9 . We use test results for $3^{\text {rd }}$ and $6^{\text {th }}$ grade students from 1998 to 2005 , allowing us to track 5 cohorts of students, starting with children who were in $3^{\text {rd }}$ grade in 1997-98, and ending with those in $3^{\text {rd }}$ grade in $2001 .^{34}$ We have data for roughly 65,000 public school students and 32,000 separate school students in each cohort.

The test data file has a limited set of individual characteristics, including gender, whether a student is classified as "exceptional" (i.e., special needs) or "gifted" (i.e., advanced), whether he or she attended kindergarten, and whether he/she is enrolled in an English-as-a-SecondLanguage (ESL) or French Immersion program. (We do not know whether a student is Catholic). Means for these characteristics by grade and public versus separate school status are shown in the upper rows of Table 4 . There are some small but statistically significant differences between students in the two systems. For example, separate school students are a little more likely to have attended kindergarten, are less likely to be classified as exceptional or gifted, and are less likely to be enrolled in ESL or French Immersion.

We limit our analysis sample to children in school-cohort groups that have at least 10 test takers in both $3^{\text {rd }}$ and $6^{\text {th }}$ grades. We also compare the number of test takers in a cohort in $3^{\text {rd }}$ and

\footnotetext{
${ }^{34}$ The tests are administered by the Education Quality and Accountability Office (EQAO). EQAO will not release test records for schools with fewer than 15 students enrolled in the grade of the test. Thus, our analysis does not include those schools with low enrollments. While many of these smaller schools are located in rural areas, some are special alternative schools located in urban areas.
} 
$6^{\text {th }}$ grades, and eliminate groups for which the ratio is greater than 1.4 or less than $0.71(=1 / 1.4) .{ }^{35}$

Our final sample includes $65-70 \%$ of all public school test takers and a higher fraction (85-96\%)

of all separate school test takers. These students are drawn from approximately 9000 schoolcohort groups who attended 2000 different schools.

Summary statistics for the test outcomes of the analysis sample are presented in the bottom rows of Table $4 .{ }^{36}$ We show mean test scores by grade and public/separate school status for the three main test components: reading, mathematics, and writing. The test results are reported on a relatively coarse scale of 1-4, with 4 representing the top score. ${ }^{37}$ The mean test score is typically around 2.6 while the standard deviation ranges from 0.6 to 0.8 . Mean test scores are quite similar in the two systems. This is quite different than the situation in the U.S., where students at Catholic schools have substantially higher scores than those at public schools. The difference is presumably attributable to the very different selectivity of Catholic school attendees when the schools are free (as in Ontario) than not (as in the U.S.). Reflecting this difference, the fraction of Catholic children in Ontario who attend separate schools is also relatively high $(65 \%$ on average) .

\section{c. Differences Between Catholic and non-Catholic Families}

As noted above, a key assumption in our research design is that students in areas with a higher or lower fraction of Catholics have similar unobserved factors that affect achievement growth. While the similarity of the test outcomes in public and separate schools in Table 4 is

\footnotetext{
${ }^{35}$ We have estimated our main models using samples with different exclusion rules and find that the coefficients estimates are similar, though typically a little smaller in absolute value, when we retain school-cohorts with a wider range of variation in the number of test takers.

${ }^{36}$ Appendix Table 4 shows the mean test score outcomes for the overall samples of test takers, and presents some information on the fractions of students whose scores are missing. Many of the missing observations are attributable to exceptional students, who are not required to take the test.

${ }^{37}$ This limited scale poses a potential attenuation problem, although the fraction of students coded with the minimum score is less than $10 \%$ while the fraction coded with the top score is less than $15 \%$.
} 
broadly consistent with this assumption, we cannot directly test it because we do not observe the religious affiliation of test-takers. Instead, we turn to two other data sources. The first is the 2001 Canadian Census, which includes information for a relatively large sample of Ontario residents on education, earnings, and religious affiliation. ${ }^{38}$ Since parental education is a powerful predictor of test scores (see e.g., Jencks and Phillips, 1998), any differences in the education of Catholic versus non-Catholic parents would indicate a problem for our research design. Likewise, since wages are strongly affected by cognitive skills (Murnane, Willet, and Levy, 1995), comparisons of earnings potentially reveal differences in cognitive skills of parents that may be correlated with those of their children. Our second data source is the National Education Longitudinal Study of 1988 (NELS), which interviewed children in $8^{\text {th }}$ grade in 1988 and followed them for the next two decades. Although NELS is U.S.-based, it has the advantage of including test score information at different ages, as well as detailed information on family background and religion.

Table 5 presents comparisons of education and wages by religious affiliation for Ontario parents in the 2001 Census. We present models in which the years of education or log weekly wages of a parent are regressed on dummies for religious affiliation, Census Metropolitan Area (CMA, the lowest level of geography identified in the public use file), and country of origin. The set of controls is relatively parsimonious, reflecting the controls that we include in our test score models (see below). The odd-numbered columns of Table 5 present models that include only a dummy for Catholic religion. In these models Catholics are compared to all other parents, including Protestants (about 35\% of parents), those with no religious affiliation (about 15\% of parents), and those with religious affiliations other than Protestant or Catholic (18\% of parents).

\footnotetext{
${ }^{38}$ The public use files of the 2001 Canadian census do not allow users to construct families. We classify as "parents" individuals between the ages of 24 and 62 who are either the head or spouse of the head of the household for a household with at least one child under the age of 16 .
} 
The specifications in the even-numbered columns include dummies for people affiliated with other religions and those with no affiliation. In these models Catholics are directly compared to Protestants. Looking across the columns, the estimates show that Catholic parents have a (modest) education and wage advantage relative to other parents as a whole, but are statistically indistinguishable from Protestant parents.

A very similar pattern holds with respect to test score outcomes of children in the NELS. Table 6 presents models for $8^{\text {th }}$ grade test score outcomes of NELS students, and for their test score gains between $8^{\text {th }}$ and $10^{\text {th }}$ grade. $^{39}$ We present results for all students (in columns 1-4) and for the subset who were attending public schools in $8^{\text {th }}$ grade (columns 5-8). The latter group is particularly interesting because few of them attend Catholic high schools (Altonji, Elder, and Taber, 2005a, 2005b). Thus, differences in test score gains between $8^{\text {th }}$ and $10^{\text {th }}$ grade arguably measure the direct impact of a Catholic family background, rather than a combination of family background effects and Catholic schooling effects.

As shown by the estimates in columns 1 and 5, when Catholics are compared to all other children, they have significantly higher $8^{\text {th }}$ grade test scores. Likewise, the models in columns 3 and 7 show faster test score gains between $8^{\text {th }}$ and $10^{\text {th }}$ grade. When the comparison group is narrowed to Protestants, however, the differences are much smaller and uniformly statistically insignificant. Thus, it appears that Catholic and Protestant children in the NELS have about the same test score levels and gains, whereas both groups do better than children with other religions or no religious affiliation, or who fail to report their affiliation. ${ }^{40}$

\footnotetext{
${ }^{39}$ NELS also has test scores in $12^{\text {th }}$ grade, but a much larger fraction of students (25\%) have missing test data.

${ }^{40}$ We have fit a wide variety of alternative models to the NELS data, including models that are fit by weighted OLS, using cross-sectional or panel weights, and models for $10^{\text {th }}$ grade scores that include $8^{\text {th }}$ grade scores on the right hand side. These models yield very similar results to the specifications reported in Table 6. Models for parental education in the NELS sample yield results that are quite similar to those in Table 5, though Catholic fathers have somewhat higher education than Protestant fathers. One important difference between Protestants in Canada and the U.S. is the higher fraction of "non-mainstream" Protestants in the U.S. When we fit models including separate
} 
Overall, we interpret the test score results from NELS as confirming the conclusions from Table 5. In particular, Catholic children in Ontario and in the US appear to have similar family background characteristics and similar test scores to Protestants. Both groups have better family characteristics and better test scores than children affiliated to other religions, or with no religious affiliation. ${ }^{41}$

\section{d. Models for Test Score Outcomes}

Table 7 presents estimation results for four alternative specifications of equation (11), fit separately to individual scores in reading, mathematics, and writing. In addition to the explanatory variables listed in the table, the models include a dummy for $6^{\text {th }}$ grade test takers, and 8 student-level controls (gender, ESL status, French immersion status, gifted or exceptional status, a dummy for kindergarten attendance, and dummies for unknown gender and kindergarten attendance). These variables are all entered with grade-specific coefficients. We also include school-cohort means of the student variables, along with the mean fraction of the group with missing test scores and the fraction with a missing score who are coded as exceptional, all interacted with an indicator for grade 6 . In addition, the models include the fraction of immigrants in the FSA, and the fractions in the FSA who report East Asian, South Asian, Northern European, Southern European, and Eastern European ethnicity, all interacted with grade 6 status. $^{42}$ The models include school $\times$ cohort fixed effects, with estimated standard errors "clustered" by school to allow for arbitrary correlation across the students from any one school.

coefficients for Baptists and Pentecostals, Catholic children have lower test scores than mainstream Protestants, and their parents have lower education than those of mainstream Protestants.

${ }^{41}$ See Lehrer (2005) for a review of evidence from the U.S. which generally concludes that religious affiliation has a positive effect on schooling outcomes.

${ }^{42}$ As Canada is historically comprised of immigrants from the United Kingdom and France, we exclude ethnicities affiliated with these countries from our European ethnic measures. In addition, we include Southern European countries previously aligned with Russia under the Eastern European ethnic grouping. 
Columns 1, 5 and 9 present a basic model that uses the local fraction of Catholics as an indicator of competitive pressure. The estimated coefficients are statistically significant and suggest that $6^{\text {th }}$ grade scores in reading and writing are about 0.06 points higher, and scores in math are about 0.12 points higher, in a $60 \%$ Catholic neighborhood than in a $20 \%$ Catholic neighborhood, holding all else constant. Since the standard deviations of $6^{\text {th }}$ grade scores across students are approximately 0.75 , these represent effect sizes of $7-16 \%$ of a standard deviation.

The models in columns 2, 6, and 10 include both the local fraction of Catholics and the fraction of Catholics interacted with the share of new housing in the neighborhood as indicators of competitive pressure. Consistent with the pattern in our enrollment growth models, the estimates for the interaction term suggest that competitive pressure is much stronger in newer neighborhoods. The specifications in columns 3, 7, and 11 exclude the Catholic share variable a restriction that is not rejected at conventional significance levels for the reading or writing models but is rejected in the mathematics model. Again, all three estimates of the competition effect are highly statistically significant. To interpret the magnitude of the estimated effects, consider the 0.39 coefficient estimate from the reading score model. Comparing an area with a $60 \%$ Catholic share and a $20 \%$ new housing share (close to the sample average) to an area with the same new housing share but only $20 \%$ Catholics, reading scores in $6^{\text {th }}$ grade are increased by 0.03 points, or an effect size of $4 \%$ of a standard deviation. The implied effect in a relatively new neighborhood (35\% new housing share) is $7 \%$ of a standard deviation. The predicted effects for writing scores are similar while the effects for mathematics are $75 \%$ larger.

Our investigation of differences between Catholics and non-Catholics suggested that Catholic parents and children are very similar to Protestants, but both groups are advantaged relative to families with other religious affiliations, or no affiliation. In view of this finding, we 
added two additional controls to the models in columns 4,8 , and 12: the fraction of people in the FSA who express no religious affiliation, and the fraction affiliated with religions other than Protestant or Catholic (i.e., Judaism, Islam, Hinduism, etc.). In these models, the effect of local competition is identified by variation in the fraction of Catholics relative to Protestants, holding constant the fractions with other religion and no religion. Provided that Catholic and Protestant children have similar unobserved determinants of test score growth (as appears to be true in the NELS), estimates from these models will provide consistent estimates of any competition effect.

The addition of these two controls attenuates the coefficient of our competition indicator slightly in the models in reading and writing, and somewhat more for mathematics, though all three coefficients remain significant at conventional levels. Consistent with the models for NELS test outcomes, a higher local fraction of people who report no religious affiliation is associated with slower test score gains, particularly in mathematics. By comparison the effects of the share of families with religious affiliations other than Protestant or Catholic are slightly positive, but not statistically significant. Interpreting the magnitudes of the competition effects, a rise of 40 percentage points in the fraction of children with choice between the systems is associated with $6^{\text {th }}$ grade test outcomes that are $4-5 \%$ of a standard deviation higher in a neighborhood with an average share of new houses.

In keeping with the simple symmetric model outlined in Section II, the specifications in Table 7 all assume that local competitive pressure has the same effect on test score gains of students at public and separate schools. In a more general model in which the incentives for gaining market share are different in the two systems, however, the effects of local competitive pressure could be different. To test this possibility, we re-estimated the specifications from columns 4, 8 and 12 of Table 7, allowing the impacts of local competitive to vary for test takers 
at public and separate schools. In the model for reading scores the coefficient of local Catholic share $\times$ new housing share is 0.49 (standard error $=0.18)$ for students at public schools, and 0.35 (standard error $=0.15$ ) for students at separate schools. In the model for mathematics scores the corresponding coefficients are 0.73 (standard error $=0.27$ ) for students at public schools and 0.50 (standard error $=0.21$ ) for students at separate schools, while in the model for writing the coefficients are 0.33 (standard error $=0.14$ ) for public school students and 0.26 (standard error $=0.12$ ) for separate school students. In all three cases the implied effects of competitive pressure are slightly larger at public schools, but in no case is the difference statistically significant.

\section{e. Interpretation}

Most families in Ontario live within a short distance of competing public and separate elementary schools. Figure 1, for example, shows the locations of schools included in our testtaker data base from the area west of Toronto. The density of the competing networks suggests there is at least a potential for cross-system competition for children of Catholic backgrounds. We interpret the results in Table 7 as suggesting that this competition leads to improved test outcomes for students in both types of schools. The pattern of competition effects - higher in faster growing areas, and proportional to the local fraction of Catholics - is consistent with direct evidence on the enrollment impacts of nearby school openings, suggesting that the effects are driven by the incentives identified in our theoretical model. Importantly, the estimated competitive effects are robust to controlling for the fraction of people with no religious affiliation, or affiliations other than Protestant or Catholic. Nevertheless, the implied effects are relatively modest: a shift between areas where $20 \%$ of students can choose between systems to 
one where $60 \%$ can choose is associated with a gain in $6^{\text {th }}$ grade test scores of about $4-5 \%$ of a standard deviation.

A limitation of our analysis is that we have no direct evidence on the actual mechanisms through which competition affects test scores. We note, however, that school-level average scores are widely reported in the media, and available from real estate agents and other sources (e.g., http://www.theschoolguy.com). There is also anecdotal evidence that teachers and principals are under pressure to raise scores. One possible mechanism for improved efficiency is through the allocation of principals and vice principals. To examine this link we tracked the identifiers for principals at each elementary school and tested whether principals tend to turn over more at schools affected by a nearby opening by the competing system in areas with a higher fraction of Catholic residents. The results did not show any systematic pattern, though clearly principal turnover is a very crude indicator of managerial input.

It is also worth noting two other limitations of our analysis. First, we can only measure test score gains over 3 years, or one-quarter of the time that most students spend in school. If similar effects were present at all stages of elementary and secondary schooling the benefits of competition would be commensurately greater. Second, it is possible that in more competitive markets teachers and principals spend more time and effort preparing for standardized tests, and less on other aspects of learning. If "test skills" have limited intellectual value, the effort devoted to competing over test outcomes is socially wasteful, and the higher test score gains observed in more competitive markets may be counter-productive. 


\section{Summary and Conclusions}

Can a reduction in the monopoly power of local school districts improve the efficiency of publicly-funded education? In this paper we try to answer this question by studying the effects of school competition in Ontario, Canada, which for over a century has operated two publicly funded school systems: "public schools" that are open to all students, and "separate schools" that are limited to children with Catholic backgrounds. The fraction of families who can exercise choice between the competing systems varies widely across different areas of the province, providing the basis for our research design.

We develop a simple model of school choice and effort competition between public and separate schools. In the model, the share of Catholic children enrolling in public schools depends on the relative quality of local public and separate schools, on their relative proximity, and on underlying tastes for a religious or secular school environment. Assuming that school managers are rewarded for larger market shares, equilibrium effort in both systems will be higher in markets with a larger share of Catholics who are willing to switch systems to access higher school quality. The model also implies that we can infer the relative responsiveness of families to school quality by measuring the fraction who "switch brands" (Bucklin, Russell, and Srinivasan, 1998) when a nearby school is opened by the rival system.

We use a comprehensive panel of elementary schools to measure the characteristics of schools and areas that lead to greater sensitivity of enrollment to changes in the nearby schools operated by the competing school system. We find that enrollment losses following a nearby school opening by the competing system are proportional to the share of Catholic families in the area, and are higher in rapidly-growing areas, where families are arguably less attached to a particular school. 
We then analyze data for five cohorts of students who wrote province-wide standardized tests in reading, mathematics, and writing in grades 3 and 6 . We model test outcomes using a value-added framework that relates the gains in scores for a cohort of student in a given school to characteristics of the students, the school, and the local area. In particular, we focus on the impact of cross-system competitive pressure, measured by the local fraction of Catholics and the interaction of this with a measure of the growth rate of housing in the area.

A key concern is that changes in the local fraction of Catholic families may have an independent effect on students' academic achievement. Since our test data lack information on religious affiliation, we use two other data sets - the 2001 Census, which contains data on educational attainment and earnings for a large sample of Ontario parents, and the National Education Longitudinal Study (NELS), which reports test score levels and changes for a large sample of children in the U.S. We find that Catholic parents and children are very similar to Protestants, but both groups are advantaged relative to families with other religious affiliations, or no affiliation. Thus, in our preferred specifications we control for the local fractions of people with no religious affiliation, or affiliations to religions other than Protestant or Catholic.

Our models show statistically significant but relatively modest effect of enhanced competition on the test score gains of local students. Comparing markets where only 20 percent of children have choice to markets where 60 percent can choose between systems, we estimate that test scores in $6^{\text {th }}$ grade are $0.04-0.05$ of a standard deviation higher, relative to $3^{\text {rd }}$ grade scores. The implied impacts are higher in rapidly growing areas and smaller in slow-growth areas. Consistent with a "market competition" effect, we find that test scores of students in both the public and separate systems are higher in areas with more competitive pressure, with somewhat larger impacts on public school students. 
Our findings have at least three implications for education policy. First, we have shown that a significant fraction of families are willing to move between publicly-funded schools to access a combination of higher quality or more convenient schools. This willingness to move provides the basis for cross-system competition that can lead, at least in principle, to improved efficiency of publicly-funded schools. Our estimates suggest competition has a modest positive effect on student achievement: extending choice to all students would lead to gains in $6^{\text {th }}$ grade test scores of $6-8 \%$ of a standard deviation. Finally, our results underscore the critical importance of further research on the links between parental choice decisions and the incentives faced by competing school systems. 


\section{References}

Ahlin, Åsa, 2003. "Does School Competition Matter? Effects of a Large-Scale School Choice Reform on Student Performance," Working Paper Series 2003:2, Uppsala University, Department of Economics

Altonji, Joseph G., Todd E. Elder and Christopher R. Taber (2005a). "Selection on Observed and Unobserved Variables: Assessing the Effectiveness of Catholic Schools." Journal of Political Economy 113 (February), pp. 151-184.

Altonji, Joseph G., Todd E. Elder and Christopher R. Taber (2005b). "An Evaluation of Instrumental Variable Strategies for Estimating the Effects of Catholic Schools." Journal of Human Resources 40 (Fall), pp. 791-821.

Arum, R. (1996). "Do Private Schools Forces Public Schools to Compete?” American Sociological Review 61 (1), pp. 29-46.

Belfield, Clive R. and Henry M. Levin (2002). "The Effects of Competition on Educational Outcomes: A Review of U.S. Evidence." Review of Educational Research 72(2), pp.279-341

Bifulco, Robert and Helen F. Ladd (2004). "The Impacts of Charter Schools on Student Achievement: Evidence from North Carolina.” Education Finance and Policy 1(1), pp.50-90.

Booker, Kevin, Scott Gilpatric, Timothy Gronberg, and Dennis Jansen (2005). "The Effect of Charter Schools on Traditional Public School Students in Texas: Are Children Who Stay Behind Left Behind?" Unpublished manuscript. Santa Monica: Rand Corportation.

Borland, M. V. and R. M. Howsen (1992). "Student Academic Achievement and the Degree of Market Concentration in Education." Economics of Education Review 11(1), pp. 31-39.

Bucklin, Randolph E., Gary J. Russell, and V. Srinivasan (1998). "A Relationship Between Market Share Elasticities and Brand Switching." Journal of Marketing Research, 35 (1), pp. 99113.

Carnoy, Martin, Rebecca Jacobsen, Lawrence Mishel, and Richard Rothstein (2005). The Charter School Dust-Up: Examining the Evidence on Enrollment and Achievement. Washinton DC: Economic Policy Institute.

Chubb, John E. and Terry M. Moe (1990). Politics, Markets, and America's Schools. Washington DC: Brookings Institution.

Clark, Damon (2005). "Politics, Markets, and Schools: Quasi-Experimental Evidence on the Impact of Autonomy and Competition from Truly Revolutionary UK Reform.” Unpublished manuscript. Gainesville FL: University of Florida Department of Economics. 
Coleman, James S., Thomas Hoffer and Sally Kilgore (1982). High School Achievement: Public, Catholic and Private Schools Compared. New York: Basic Books.

Couch, J.F., William F. Shughart II. And A. L. Williams (1993). "Private School Enrollment and Public School Performance.” Public Choice 76(4), pp. 301-312.

Dee, Thomas S. (1998). "Competition and the Quality of Public Schools.” Economics of Education Review 17(4), pp. 419-427.

Epple, Dennis and Richard E. Romero (1999). "Competition Between Private and Public Schools, Vouchers, and Peer-Group Effects." American Economic Review 88 (March), pp. 3362.

Evans, William N. and Robert M. Schwab (1995). "Finishing High School and Starting College: Do Catholic Schools Make a Difference?” Quarterly Journal of Economics 110 (November), pp. 941-974.

Figlio, David and Jens Ludwig (2000). "Sex, Drugs, and Catholic School: Private Schooling and Adolescent Non-Market Behavior.” National Bureau of Economic Research Working Paper \#7990. Cambridge MA: NBER.

Friedman, Milton. (1955). "The Role of Government in Education." In Robert A. Solo, editor, Economics and the Public Interest. New Brunswick New Jersey: Rutgers University Press.

Geller, Christopher R., David L. Sjoquist, and Mary Beth Walker (2006). "The Effect of Private School Competition on Public School Performance in Georgia." Public Finance Review 34 (January), pp. 4-32.

Gibbons, Stephen, Stephen Machin, and Olmo Silva. (2006). "Choice, Competition and Pupil Achievement," IZA Discussion Papers 2214, Institute for the Study of Labor (IZA).

Goldberger, Arthur S. and Glen C. Cain (1982). "The Causal Analysis of Cognitive Outcomes in the Coleman, Hoffer and Kilgore Report." Sociology of Education 55 (April-July), pp. 103-122.

Grogger, Jeffrey and Derek Neal (2000). "Further Evidence on the Benefits of Catholic Secondary Schooling." Brookings-Wharton Papers Urban Affairs, pp. 151-193.

Hanushek, Eric A. (2003). “The Failure of Input-Based Schooling Policies.” Economic Journal 113 (February), pp. F64-F98.

Hastings, Justine, Thomas Kane, and Douglas Staiger. (2006). "Parental Preferences and School Competition: Evidence from a Public School Choice Program." National Bureau of Economic Research Working Paper No. 11805. Cambridge, MA: NBER.

Howell, William G. and Paul E. Petersen (2002). The Education Gap: Vouchers and Urban Schools. Washington DC: Brookings Institution. 
Hoxby, Caroline M. (1994). "Do Private Schools Provide Competition for Public Schools?" National Bureau of Economic Research Working Paper No. 4978. Cambridge, MA: NBER.

Hoxby, Caroline M. (2004). "Achievement in Charter Schools and Regular Schools in the United States: Understanding the Differences" Unpublished manuscript. Cambridge MA: Harvard University Department of Economics.

Hsieh, Chang-Tai and Miguel Urquiola (2006). "The Effects of Generalized School Choice on Achievement and Stratification: Evidence from Chile's Voucher Program." Journal of Public Economics 90, pp. 1477-1503.

Jencks, Christopher and Meredith Phillips, editors (1998). The Black-White Test Score Gap. Washington DC: Brookings Institution.

Jepsen, Christopher (2002). "The Role of Aggregation in Estimating the Effects of Private School Competition on Student Achievement." Journal of Urban Economics 52, pp. 477-500.

Jepsen, Christopher (2003). "The Effectiveness of Catholic Primary Schooling.” Journal of Human Resources 38 (Fall), pp. 928-941.

Krueger, Alan B. and Pei Zhu (2004). "Another Look at the New York City School Voucher Experiment." American Behavioral Scientist 47, pp. 658-98

Ladd, Helen F. (2002). "School Vouchers: A Critical View." Journal of Economic Perspectives 16 (Fall), pp. 3-24.

Lehrer, Evelyn L. (2005). "Young Women's Religious Affiliation and Participation as Determinants of High School Completion." IZA Working Paper No. 1818, October.

Murnane, Richard J., John B. Willett, and Frank Levy. (1995). "The Growing Importance of Cognitive Skills in Wage Determination." The Review of Economics and Statistics, 77(2), pp. 251-66.

Nechyba, Thomas. (2000). "Mobility, Targeting and Private School Vouchers." American Economic Review 90 (March), pp. 130-146.

Neal, Derek (1997). "The Effects of Catholic Secondary Schooling on Educational Attainment." Journal of Labor Economics 15 (January), pp. 98-123.

Nevo, Aviv.(2000) "A Practitioner's Guide to Estimation of Random Coefficients Logit Models of Demand," Journal of Economics \& Management Strategy, 9(4), pp. 513-548.

Newmark, Craig M. (1995). "Another Look at Whether Private Schools Influence Public School Quality.” Public Choice 82(3/4), pp. 365-373. 
Millimet, Daniel L. and Vasudha Rangaprasad (2006). "Strategic Competition Amongst Public Schools.” Regional Science \& Urban Economics, forthcoming.

Ontario Ministry of Education (2005). "The Ontario Curriculum, Grades 1-8: Mathematics." Available at http://www.edu.gov.on.ca/eng/curriculum/elementary/math18curr.pdf.

Rivkin, Steven G., Eric Hanushek, and John F. Kain (2005). "Teachers, Schools, and Academic Achievement." Econometrica 73, pp. 417-458.

Rothstein, Jesse (2006a). "Good Principals or Good Peers: Parental Valuation of School Characteristics, Tiebout Equilibrium, and the Incentive Effects of Competition Among Jurisdictions.” American Economic Review 96(4), pp. 1333-1350.

Rothstein, Jesse (2006b).”Does Competition Among Public Schools Benefit Students and Taxpayers? A Comment on Hoxby (2000).” American Economic Review (forthcoming).

Sander, William (1999). "Private Schools and Public School Achievement." Journal of Human Resources 34 (Autumn), pp. 697-709. 


\section{Appendix 1: Multiple Schools Equilibrium}

This appendix extends the model developed in the text to the case where there are multiple schools operated by each of the two competing systems. To simplify notation, define a neighborhood by the identity of its assigned schools: thus students in neighborhood $(\mathrm{j}, \mathrm{k})$ can attend either public school $\mathrm{j}$ or separate school $\mathrm{k}$. Let $\mathrm{n}_{2 \mathrm{jk}}$ represent the number of Catholic students in neighborhood $(\mathrm{j}, \mathrm{k})$ and let

$$
\mathrm{s}_{\mathrm{jk}}\left(\Delta \mathrm{Q}_{\mathrm{jk}}, \Delta \mathrm{t}_{\mathrm{jk}}\right)=\int \mathrm{F}\left[\delta_{\mathrm{i}}+\beta \Delta \mathrm{Q}_{\mathrm{jk}}-\gamma \Delta \mathrm{t}_{\mathrm{jk}}\right] \mathrm{h}\left(\delta_{\mathrm{i}} \mid \mathrm{j}, \mathrm{k}\right) \mathrm{d} \delta_{\mathrm{i}}
$$

represent the share of these students who attend public school $\mathrm{j}$, given the quality differential $\Delta \mathrm{Q}_{\mathrm{jk}}$ and relative travel costs $\Delta \mathrm{t}_{\mathrm{jk}}$. Public school $\mathrm{j}$ 's attendance zone includes $\mathrm{n}_{1 \mathrm{j}}$ non-Catholic students and $\mathrm{n}_{2 \mathrm{j}}=\Sigma_{\mathrm{k}} \mathrm{n}_{2 \mathrm{jk}}$ Catholic students (with similar expressions for separate school $\mathrm{k}$ ). Total enrollment at public school $\mathrm{j}$ is therefore

$$
E_{j}=n_{1 j}+n_{2 j} \Sigma_{k} n_{2 j k} / n_{2 j} s_{j k}\left(\Delta Q_{j k}, \Delta t_{j k}\right)
$$

while total enrollment at separate school $\mathrm{k}$ is

$$
\mathrm{E}_{\mathrm{k}}=\mathrm{n}_{2 \mathrm{k}} \Sigma_{\mathrm{j}} \mathrm{n}_{2 \mathrm{jk}} / \mathrm{n}_{2 \mathrm{k}}\left(1-\mathrm{S}_{\mathrm{jk}}\left(\Delta \mathrm{Q}_{\mathrm{jk}}, \Delta \mathrm{t}_{\mathrm{jk}}\right)\right)
$$

Assuming that school quality depends on managerial effort as before, and that school managers have the same objective function specified earlier, the first order condition for the effort choice of the manager of the $\mathrm{j}^{\text {th }}$ public school is

$$
\theta\left(\mathrm{n}_{2 \mathrm{j}} / \mathrm{n}_{\mathrm{j}}\right)\left\{\Sigma_{\mathrm{k}}\left(\mathrm{n}_{2 \mathrm{jk}} / \mathrm{n}_{2 \mathrm{j}}\right) \partial \mathrm{s}_{\mathrm{jk}}\left(\Delta \mathrm{Q}_{\mathrm{jk}}, \Delta \mathrm{t}_{\mathrm{jk}}\right) / \partial \Delta \mathrm{Q}\right\} \mathrm{q}^{\prime}\left(\mathrm{e}_{\mathrm{j}}\right)-1=0
$$

while the corresponding condition for the manager of the $\mathrm{k}^{\text {th }}$ separate school is

$$
\theta\left(\mathrm{n}_{2 \mathrm{k}} / \mathrm{n}_{\mathrm{k}}\right)\left\{\Sigma_{\mathrm{j}}\left(\mathrm{n}_{2 \mathrm{jk}} / \mathrm{n}_{2 \mathrm{k}}\right) \partial \mathrm{s}_{\mathrm{jk}}\left(\Delta \mathrm{Q}_{\mathrm{jk}}, \Delta \mathrm{t}_{\mathrm{jk}}\right) / \partial \Delta \mathrm{Q}\right\} \mathrm{q}^{\prime}\left(\mathrm{e}_{\mathrm{k}}\right)-1=0
$$

As a benchmark, consider the case in which: (i) the distribution of tastes is the same in all neighborhoods (i.e., $\mathrm{h}\left(\delta_{\mathrm{i}} \mid \mathrm{j}, \mathrm{k}\right)=\mathrm{h}\left(\delta_{\mathrm{i}}\right)$ ); (ii) relative travel costs are the same in all neighborhoods 
(i.e., $\Delta \mathrm{t}_{\mathrm{jk}}=\Delta \mathrm{t}$ ); (iii) the relative fraction of Catholic students is constant and equal to $\mathrm{n}_{2} / \mathrm{n}$ across all neighborhoods. Under these conditions,

$$
\mathrm{s}_{\mathrm{jk}}\left(\Delta \mathrm{Q}_{\mathrm{jk}}, \Delta \mathrm{t}_{\mathrm{jk}}\right)=\mathrm{s}\left(\Delta \mathrm{Q}_{\mathrm{jk}}, \Delta \mathrm{t}\right) \equiv \int \mathrm{F}\left[\delta_{\mathrm{i}}+\beta \Delta \mathrm{Q}_{\mathrm{jk}}-\gamma \Delta \mathrm{t}\right] \mathrm{h}\left(\delta_{\mathrm{i}}\right) \mathrm{d} \delta_{\mathrm{i}},
$$

and the effort game has a symmetric equilibrium with $\mathrm{e}_{\mathrm{j}}=\mathrm{e}_{\mathrm{k}}=\mathrm{e}^{*}$, where $\mathrm{e}^{*}$ satisfies the condition (A3) $\theta\left(\mathrm{n}_{2} / \mathrm{n}\right) \partial \mathrm{s}(0, \Delta \mathrm{t}) / \partial \Delta \mathrm{Q} \mathrm{q}^{\prime}\left(\mathrm{e}^{*}\right)-1=0$.

This is the same as the equilibrium condition in the two-school case given by equation (6) in the text.

More generally, in a multi-school setting the incentives for effort of the manager of a given school depend on the fraction of students in the catchment area who can potentially move to the other system, and on a weighted average of the derivatives of the enrollment share in each neighborhood with respect to relative school quality (i.e., $\left.\Sigma_{\mathrm{k}}\left(\mathrm{n}_{2 \mathrm{jk}} / \mathrm{n}_{2 \mathrm{j}}\right) \partial \mathrm{s}_{\mathrm{jk}}\left(\Delta \mathrm{Q}_{\mathrm{jk}}, \Delta \mathrm{t}_{\mathrm{jk}}\right) / \partial \Delta \mathrm{Q}\right)$. As in the simpler two-school setting, this derivative is closely related to the sensitivity of enrollment to a change in the number of nearby schools operated by the competing system. In particular, using a slight modification of equations (7) and (8) it is easy to show that schools with market shares that are more sensitive to quality will lose more students when the opposing system opens a new school nearby. 


\section{Appendix 2: Construction of Schools and Test Score Data}

All data on Ontario schools were obtained from the Ministry of Education under several Freedom of Information Requests. The following basic school information was provided: school identification number, school name, school type, board affiliation, and last known address. ${ }^{43}$ This information was requested for all schools that were in existence at any point from 1990 to the present. From this information, we identified a set of publicly funded, English speaking public and separate schools. This set of schools includes French Immersion programs in English speaking schools. From this set of schools, we excluded any school that we could identify as being a school operated for the mentally ill, prisons, and other types of special populations. ${ }^{44}$

For each school year, the Ministry provided enrollments for each grade based on the fall enrollment reports the schools were required to complete. From these enrollment figures we identified the set of schools for which a school had positive enrollment for one or more grades between 1 st and 6 th grades during the sample period.

Identification of an Opening or Closing

We tracked openings and closings of schools that offer grades 2, 3, and/or 4 in the opening or closing year. ${ }^{45}$ To be classified as an opening school, enrollment in these grades must be positive in a given year (the "opening year") and total enrollment must be zero in previous years. Similarly, to be classified as a closing school, enrollment in grades 2, 3, and/or 4 must be positive in a given year and total enrollment must be zero in the next year (the "closing year") and all subsequent years. We ignore schools that open and close in the same year (i.e., only have

\footnotetext{
${ }^{43}$ If a school moved locations during the period under study, we do not observe the move.

${ }^{44}$ In the data cleaning process we excluded the following types of schools: schools whose address is located outside of the province; schools whose primary population are prisoners or infirmed individuals; schools that only offer kindergarten; schools on First Nation reserves; schools that never report a positive enrollment.

${ }^{45}$ This results in our excluding from an analysis "middle" schools that open or close during the sample period. In Ontario, most schools offer all grades between 1 st and 8 th grade.
} 
positive enrollment in a single calendar year). Note that schools that expand or contract their grade offerings are not treated as opening or closing. Similarly, in a few situations, schools are paired together for administrative purposes. When this occurs provincial records show that both schools remain in operation but enrollment for the two is reported at only one of the schools. We identified these "pairing events" and validated their status with information from the Ministry of Education. We ignore enrollment changes arising from pairing events in the identification of an opening or closing.

Special considerations:

- Schools that change grades. There are a few schools that add or drop grades over time. Because these schools were in existence and continue to be in existence we do not treat them as openings or closings.

- There are some schools that close, remain closed for several years and then reopen. After confirming that the school has not been an annexed school in the intervening years (effectively remaining open during the period it appears to have been closed), we treat these events as separate events. We identified the following three events:

o School closed in 1991 and then reopened in 1995.

o School closed in 1993 and reopened in 1999.

o School closed in 1995 and reopened in 1997.

- There are a few schools that appear to close in one year and within the next two years another school opens in the same location. Depending on changes in enrollments we either classify the schools as separate events or assume the events represent more of a "name" change than a true closing and opening. We identified seven sets of events that we concluded should not be treated as either closing or opening events.

- If a school slowly opens or slowly closes (e.g. increases/decreases the grades offered), we will modify the enrollment figures used in our analysis to reflect the change in enrollment for the appropriate cohorts of students (e.g. if a school opens and initially offers grades 1-3 but then expands to include grades 4-6, we will measure the change in enrollment to reflect enrollments for grades 1-3 in year t-1 and grades 2-4 in year $t$ ) if that school is used in the analysis (it is affected by another school that opens or closes). The year used to identify the opening or closing, however, is the first/last year the school is observed with positive enrollment, respectively. 


\section{Linking of school data to test scores}

Beginning in school year 1998, all publicly funded schools were required to participate in the testing of students in grades 3 and 6 using a test instrument developed by the Educational Quality and Accountability Office ("EQAO"). The EQAO tests were designed to help schools and school boards obtain a better understanding of the effectiveness of the curriculum on obtaining student achievement. To date, performance on the EQAO test does not formally affect a school's budget. The test is given in the spring of each academic year. For each of three components mathematics, reading, and writing), a student is scored on a scale of 1-4. Over time the duration and other aspects of the test have changed. The scale, however, has remained constant with 1 representing a well below expectations and 4 representing an exceeds expectation score.

For schools with more than $\mathbf{1 5}$ students, we obtained through a series of Freedom of Information requests student level data that contain information on student characteristics and performance on the three components of the test (mathematics, reading, and writing). We were provided with records for all students that should have sat the EQAO test. Thus, we were provided with records of students who only sat for part of the test and who did not sit for any of the test. To help control for issues of selection bias from students that might not have randomly not sat the exam, we were able to identify for each grade and school the share of test takers with no test score and whether these test takers were identified as receiving special education status. ${ }^{46}$

We compared the number of potential test takers by grade with the fall enrollment figures we had for the schools. Given the enrollment figures were obtained in the fall and the test was administered in the spring, we expected there to be some slippage in the enrollment and test taker counts. In instances where there was a substantial discrepancy in these counts, we investigated

\footnotetext{
${ }^{46}$ Over time, the method used to classify students as receiving special education has changed slightly. For each test year we attempted to use a consistent method for identifying these students given these constraints. For more information on how we addressed and various other issues on student characteristics, please contact the authors.
} 
the data further. In some instances the school's unique identifier was miscoded. Because we were given the name of the school, we were able to use hand checking to identify the appropriate school number to use in order to match the test level data with the school level data.

As explained in more detail in the paper, we observed that some schools had dramatically low numbers of students for whom we observe a test score. To refine our estimation, we excluded schools with a high number of non-test takers.

\section{Linking of school data to Census and location measures}

For each school we were given the last known address. We used the first three characters of the postal code to identify the "Forward Sortation Area" (FSA) of the school. Using the FSA we then matched census data from 1991, 1996, and 2001 to schools. If the current FSA did not exist for earlier years, we identified the FSA that most likely was covered historically and used census measures across all three periods that corresponded to the area covered by the school for

all three census years. In some instances the FSA census data were suppressed and/or it was clear that the area covered by the FSA did not represent the area that was likely to be the school's catchment area. This usually occurred in rural areas where there was a small town that had a distinct FSA from the rural parts. We used the census measures for the broader area when it was clear that a school's enrollment included families residing in both the rural area and the small town.

For each school address, we used data provided by researchers at Carleton University to identify the longitude and latitude of each school location. If instances where the school address as given as a post office box, we used the longitude and latitude for the centroid of the postal code. For more information on the data from this source, please see www.geocoder.ca. 


\section{Appendix 3: Construction of Circle Data Set}

For each opening and closing school we constructed a "pre-defined" circle based on the average distance traveled by students to schools in the area. ${ }^{47}$ We then refined the circle by excluding schools that were identified to be within the circle for which there is a physical obstacle preventing it from being a reasonable competitor. These obstacles include expressways, ravines, and industrial/commercial areas. We also included schools that were outside of the predefined circle if it appeared that the school was close enough to the opening/closing school to be a potential competitor. Our judgments were based on an examination of detailed satellite images that mapped the school addresses. In instances where the satellite image was unclear and/or the few school addresses that could not be found by the mapping software, we used print maps of Ontario streets that contain markers for existing and many previously existing schools. ${ }^{48}$

Across the 735 identified changes, we identified at least one school in 559 circles. There are 58 public openings, 35 separate openings, 74 public closings, and 10 separate closures for which there were no existing schools within a reasonable distance. We then eliminated circles that contained only rural schools that were affected by the change. This leaves a total of 442 changes that affected at least one non-rural school. Appendix Table 5 presents summary statistics on the refined circles we have selected by type of change.

\footnotetext{
${ }^{47}$ For more recent years of the school enrollment data, we were able to obtain counts of students attending the school based on their postal codes. This type of data is somewhat noisy as when compared with the location of the school there can be unrealistic distances between the students home postal code and the school. Moreover, we have this information for only those schools that were operating in the latter years of the sample. We, therefore, used this information to identify a baseline circle size of the catchment area of schools located in a given region.

${ }^{48}$ To define the circles, we used the latitude and longitude of the school based on its most recent street address. While information on latitude and longitude is publicly available from several sources, we found the most reliable source of this information from www.geocoder.ca. The individuals that provide this service have taken publicly available data and corrected them. Through our examination of printed maps and satellite images, we randomly confirmed that the information we received from Geocoder was better than the information from government sources.
} 
In Panel B of Appendix Table 5 we report statistics on the circles for which we identified at least one non-rural affected school. The share of circles with existing public schools ranges from 86 to 100 percent. The share of circles with existing separate schools ranges between 73 and 95 percent. For approximately $20-25$ percent of the opening circles and $60-65$ percent of the closing circles we excluded schools that were identified in the pre-defined circles. For approximately 55-65 percent of the opening schools and 43-50 percent of the closing schools we added schools that are located outside of the pre-defined circle. A small proportion of the openings and closings only use schools located outside of the pre-defined circle.

\section{Example of Circle Modification}

Elkhorn Public School opened in 1996 in North York, a community that is a part of the Toronto District School Board. ${ }^{49}$ In 1996 it had a total enrollment of 297 students. Students were enrolled in grades from kindergarten to grade 4. In 1997, enrollment grew to 371 and the school had students enrolled from kindergarten to grade 5. For the rest of the sample period, this school has had students enrolled in all of these grades. Approximately 65 percent of the students have a primary language other than English.

For this area, we estimated an average distance to school of 2.2 kilometers. We identified and mapped all schools that were in operation at the time of the opening up to 3.2 kilometers. For these schools we mapped the location (based on their addresses) using a satellite image and using printed maps that contain the specific location of schools. Below is a depiction of those schools that were within a radius of just less than 2.2 kilometers. We do not depict the school that are beyond 2.2. kilometers from the school as the decision of whether to keep it was based on the decision regarding Lescon Public School (a school within the 2.2 kilometer radius).

\footnotetext{
${ }^{49}$ On the location of this school, there was a public school that closed in 1985.
} 
Depicted are 10 schools, 7 are public and 3 are separate. Among the public schools is Bayview Middle School. Until 1995 it offered grades kindergarten to grade 8. From 1996 onwards, the school has only offered grades 6 to 8 . Thus, it appears that, in part, Elkhorn was established to take over the enrollment for Bayview. Another public school in the area is Avondale Elementary Alternative School. The school is alternative in that it allows for selfdirected learning. It covers all elementary grades. Since opening (in 1992), the enrollment has been just slightly under 100 students. The remaining 5 public schools have average enrollments in grades 1 to 6 during the sample period that range between 126 and 281 students. Of the three separate schools depicted, average enrollment in grades 1 to 6 ranged between 163 and 296 students over the sample period.

There are two issues that caused us to restrict the sample of schools treated as being within a close distance of the opened school. First, there is a major freeway (Highway 401) that is located south of Elkhorn. This resulted the in the exclusion of Dunlace and Harrison Public Schools. Second, there is a ravine. This excluded two of the three separate schools (Blessed Trinity and St. Mathias) and one of the public schools (Lescon). The remaining schools are located within 2 kilometers of Elkhorn. Given students could reside in areas between Elkhorn and these schools, it seems reasonable to include these schools as ones that are potentially affected by the opening.

This leaves, however, only one potentially competing separate school. Blessed Trinity is just beyond the ravine and is close to Finch Public School, a school that is treated as within the circle of the opening. Figure 2 provides a more detailed image of the area around Blessed Trinity. Figure 2 shows that Blessed Trinity and Finch schools are separated by two major roads. Moreover, there are few houses that lie in between these schools. It appears that Blessed Trinity 
draws its students from the houses that are located north east of the school, an area that is farther away from Elkhorn. Therefore, we decided that this school should not be treated as being potentially affected by the opening. 
Figure A3-1

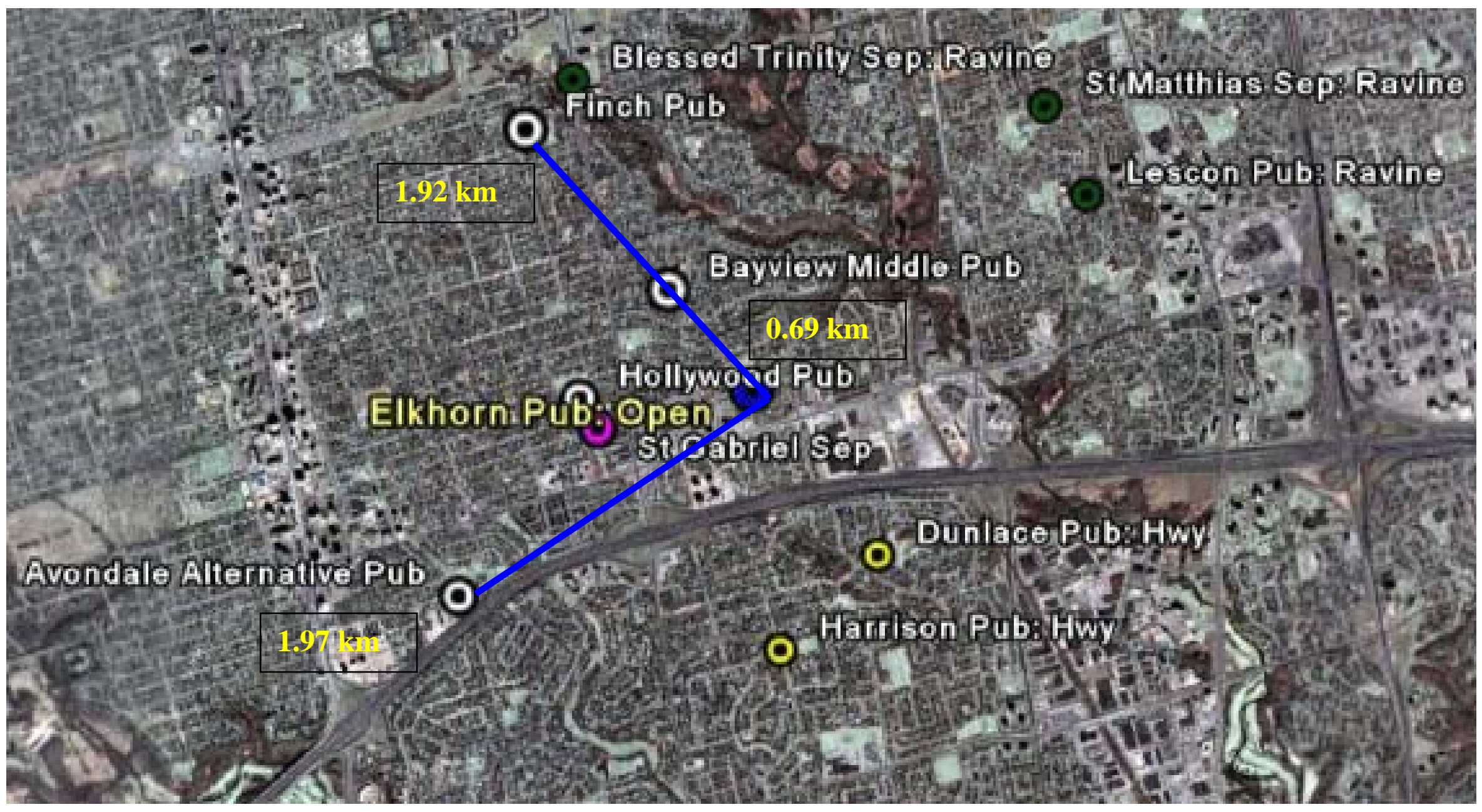


Figure A3-2

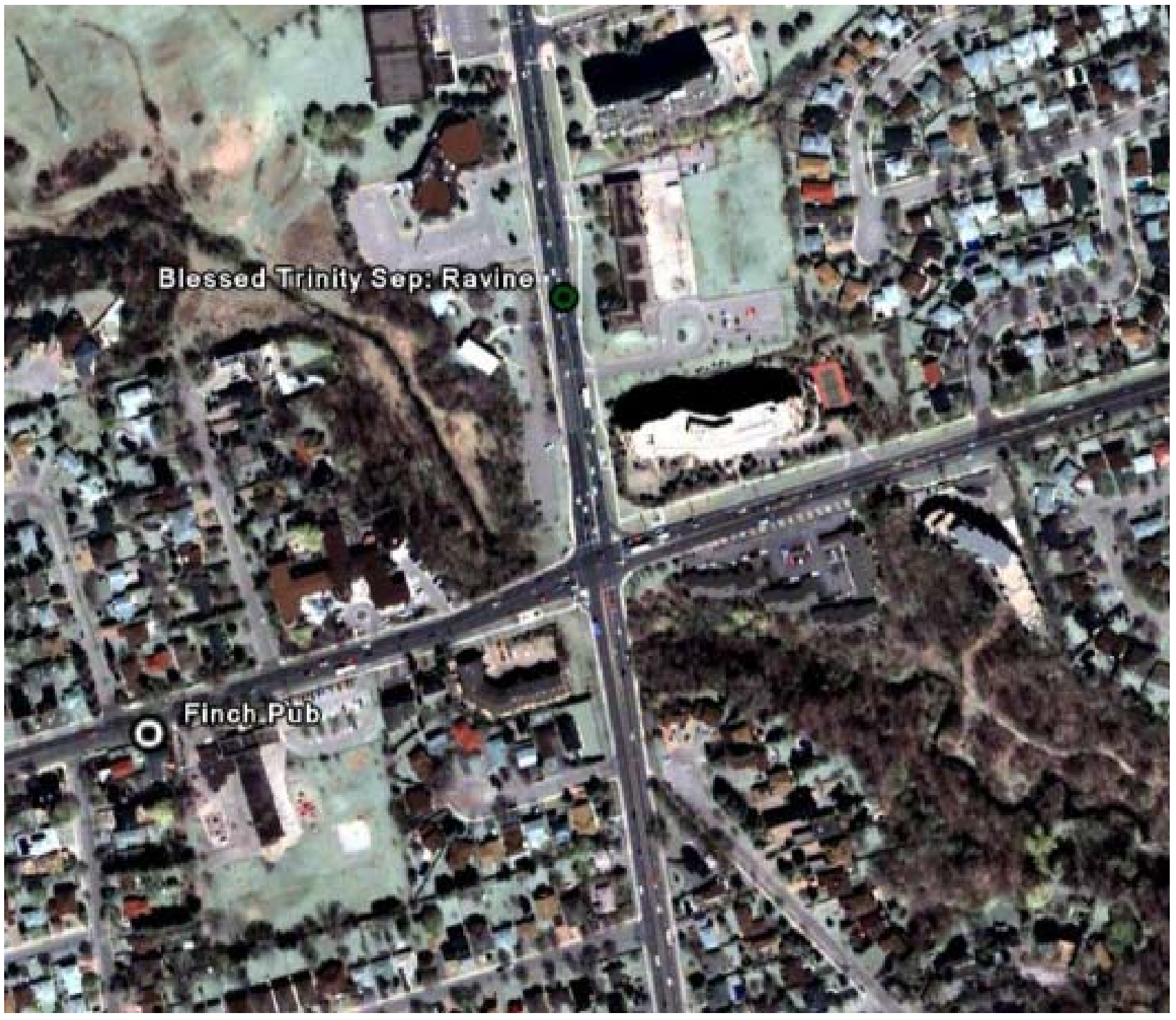




\section{Appendix Table 1: Census-Based Characteristics of non-Rural FSA's wl School Changes}

\begin{tabular}{|c|c|c|c|c|}
\hline & \multicolumn{4}{|c|}{ Mean for FSA's with: } \\
\hline & No Changes & $\begin{array}{c}\text { School } \\
\text { Openings }\end{array}$ & $\begin{array}{c}\text { School } \\
\text { Closings }\end{array}$ & $\begin{array}{l}\text { Openings } \\
\text { \&Closings }\end{array}$ \\
\hline 1. Number of FSA's & 215 & 77 & 92 & 45 \\
\hline \multicolumn{5}{|l|}{ Basic FSA Characteristics: } \\
\hline 2. Total population & 24,177 & 29,832 & 25,361 & 30,960 \\
\hline 3. Share of Houses Built Between 1991-2001 & $16.40 \%$ & $32.59 \%$ & $6.74 \%$ & $14.13 \%$ \\
\hline \multicolumn{5}{|l|}{ Presence of Children: } \\
\hline 4. Share of population age 5-9 & $6.4 \%$ & $7.7 \%$ & $5.8 \%$ & $6.5 \%$ \\
\hline 5. Share of population age $10-14$ & $6.5 \%$ & $7.7 \%$ & $5.8 \%$ & $6.6 \%$ \\
\hline \multicolumn{5}{|l|}{ Family Characteristics: } \\
\hline 7. Share Single Parent Families & $22.95 \%$ & $17.65 \%$ & $28.46 \%$ & $24.59 \%$ \\
\hline 8. Share with 1 Child & $42.71 \%$ & $36.88 \%$ & $45.62 \%$ & $42.12 \%$ \\
\hline 9. Share with $2+$ Children & $39.48 \%$ & $43.68 \%$ & $37.77 \%$ & $40.32 \%$ \\
\hline \multicolumn{5}{|l|}{ Education (Adult Population): } \\
\hline 10. Share with University Degree & $23.25 \%$ & $24.32 \%$ & $22.23 \%$ & $19.79 \%$ \\
\hline 11. Share without High School Diploma & $27.33 \%$ & $24.06 \%$ & $30.63 \%$ & $28.09 \%$ \\
\hline \multicolumn{5}{|l|}{ Language, Nativity and Ethnicity: } \\
\hline 12. Share that Speak English at Home & $90.40 \%$ & $93.18 \%$ & $88.16 \%$ & $94.26 \%$ \\
\hline 13. Share Immigrants & $23.79 \%$ & $32.93 \%$ & $28.99 \%$ & $21.23 \%$ \\
\hline 14. Share Southwest Asian Ancestry & $4.38 \%$ & $8.63 \%$ & $4.33 \%$ & $2.69 \%$ \\
\hline 15. Share East Asian Ancestry & $5.70 \%$ & $9.88 \%$ & $8.09 \%$ & $4.55 \%$ \\
\hline 16. Share North European Ancestry & $13.50 \%$ & $10.14 \%$ & $11.55 \%$ & $14.35 \%$ \\
\hline 17. Share South European Ancestry & $9.50 \%$ & $15.26 \%$ & $13.24 \%$ & $9.57 \%$ \\
\hline 18. Share East European Ancestry & $10.93 \%$ & $9.92 \%$ & $11.11 \%$ & $10.44 \%$ \\
\hline \multicolumn{5}{|l|}{ Religious Affiliation: } \\
\hline 19. Share Catholic & $35.27 \%$ & $38.53 \%$ & $40.21 \%$ & $33.21 \%$ \\
\hline 20. Share Protestant & $40.96 \%$ & $35.88 \%$ & $33.60 \%$ & $44.70 \%$ \\
\hline 21. Share Other Religions & $8.83 \%$ & $12.16 \%$ & $10.70 \%$ & $6.70 \%$ \\
\hline 22. Share No Religion & $14.95 \%$ & $13.42 \%$ & $15.50 \%$ & $15.39 \%$ \\
\hline
\end{tabular}

Note: based on FSA-tabulations of 1991-1996-2001-2006 Censuses.

Religious measures, however, are available only for 1991 and 2001 Censuses 


\section{Appendix Table 2: Distribution of Affected Schools by Numbers of Opening and Closing Events that Affect the School}

\begin{tabular}{lcccc}
\hline & \multicolumn{4}{c}{ Number of Closings: } \\
\cline { 2 - 5 } & None & $\begin{array}{c}\text { One } \\
\text { Closing }\end{array}$ & $\begin{array}{c}\text { Two } \\
\text { Closings }\end{array}$ & $\begin{array}{c}\text { Three- } \\
\text { Four } \\
\text { Closings }\end{array}$ \\
\hline & & & & \\
Number of Openings: & 0 & 337 & 101 & 24 \\
None & 272 & 48 & 12 & 9 \\
One Opening & 90 & 7 & 1 & 0 \\
Two Openings & 34 & 0 & 0 & 0 \\
Three Openings & 18 & 0 & 0 & 0 \\
Four-Six Openings & & & & \\
\hline Note: Sample of affected & & & & \\
\end{tabular}

Note: sample of affected schools includes only non-rural schools. 


\section{Percentage Change in Enrollment \\ Grade 1 (t-1) Grades 1-5 (t-1) \\ to Grade $1(\mathrm{t}) \quad$ to Grades 2-6 (t)}

Effects of Nearby Closings (trend shift in following 3 years) Own Effects:

\section{Effect on Public School of Public Closing}

2. Effect on Separate School of Separate Closing

\section{Cross Effects:}

3. Effect on Separate School of Public Closing

4. Effect on Public School of Separate Closing

School fixed effects and Year Dummies

Time-varying school characteristics

Time-varying local characteristics

Base Opening Measures

Interaction Opening \& Share New Housing

Interaction Opening \& Share Catholic

Interaction Opening \& Share Catholic*Share New Housing

Number of Observations

Number of Schools

4.7
$(1.5)$
7.7
$(3.7)$

4.8
$(0.9)$
6.1
$(1.2)$

4.7
$(0.9)$
6.0
$(1.2)$

$-0.6$

(1.6)

1.3

$$
(0.6)
$$

(1.6)

(0.9)

\section{Yes}

Yes

Yes

Yes

No

No

No

11,887

939

Yes
Yes
Yes
Yes
No
No
No
12,007
945

4.8
$(0.9)$
6.1
$(1.2)$

4.8
$(0.9)$
6.1
$(1.2)$

4.7
$(0.9)$
6.0
$(1.2)$

4.7

6.0
$(1.2)$

$\begin{array}{ccccc}0.3 & 0.5 & 0.5 & 0.3 & 0.4 \\ (0.6) & (0.6) & (0.6) & (0.6) & (0.6) \\ -0.8 & -0.8 & -0.8 & -0.8 & -0.8\end{array}$

$\begin{array}{llll}(0.9) & (0.9) & (0.9) & (0.9)\end{array}$

Note: standard errors in parentheses. School characteristics are a dummy for being paired with another school for administrative purposes. Local characteristics are share of enrolled students in the FSA attending public French and private schools, total population in the FSA and shares of population ages 5-9 and 10-14, fraction of FSA residents who are Catholic, fraction who are immigrants, fractions of FSA residents of East Asian, South

Asian, and Northern, Southern, and Eastern European ancentry, fraction of population with a university degree, fraction with no high school degree, fraction of single-headed families, fraction of families with 2 or 3 kids, and fraction of adults with home language other than English. British or French ancentry treated as equivalent to

"Canadian". Eastern European ancentry groups includes countries formerly affiliated with the U.S.S.R. 


\begin{tabular}{|c|c|c|c|c|}
\hline & \multicolumn{2}{|c|}{ Public Schools } & \multicolumn{2}{|c|}{ Separate Schools } \\
\hline & $\begin{array}{l}\text { Grade } 3 \\
(1)\end{array}$ & $\begin{array}{c}\text { Grade } 6 \\
(2)\end{array}$ & $\begin{array}{c}\text { Grade } 3 \\
(3)\end{array}$ & $\begin{array}{c}\text { Grade } 6 \\
(4)\end{array}$ \\
\hline \multicolumn{5}{|l|}{ Reading Tests } \\
\hline 1. Number of observations & 293,146 & 327,443 & 154,565 & 167,482 \\
\hline $\begin{array}{l}\text { 2. Average Score (1-4 Scale) } \\
\text { (standard deviation) }\end{array}$ & $\begin{array}{l}2.52 \\
(0.76)\end{array}$ & $\begin{array}{l}2.68 \\
(0.75)\end{array}$ & $\begin{array}{l}2.52 \\
(0.75)\end{array}$ & $\begin{array}{c}2.70 \\
(0.73)\end{array}$ \\
\hline 3. Share of Students with Missing Score & 0.12 & 0.08 & 0.11 & 0.07 \\
\hline 4. Share of Missing Students Identified as Exceptional & 0.23 & 0.12 & 0.26 & 0.14 \\
\hline 5. Share Included in Analysis Sample & 0.73 & 0.70 & 0.96 & 0.91 \\
\hline \multicolumn{5}{|l|}{ Mathematics Tests } \\
\hline$\overline{6 .}$ Number of observations & 314,614 & 330,125 & 160,318 & 168,228 \\
\hline $\begin{array}{l}\text { 7. Average Score (1-4 Scale) } \\
\text { (standard deviation) }\end{array}$ & $\begin{array}{l}2.73 \\
(0.75)\end{array}$ & $\begin{array}{l}2.69 \\
(0.81)\end{array}$ & $\begin{array}{l}2.67 \\
(0.73)\end{array}$ & $\begin{array}{l}2.68 \\
(0.79)\end{array}$ \\
\hline 8. Share of Students with Missing Score & 0.09 & 0.08 & 0.08 & 0.06 \\
\hline 9. Share of Missing Students Identified as Exceptional & 0.23 & 0.12 & 0.28 & 0.14 \\
\hline 10. Share Included in Analysis Sample & 0.73 & 0.72 & 0.96 & 0.92 \\
\hline \multicolumn{5}{|l|}{ Writing Tests } \\
\hline 11. Number of observations & 302,282 & 333,240 & 158,770 & 169,743 \\
\hline $\begin{array}{l}\text { 12. Average Score (1-4 Scale) } \\
\text { (standard deviation) }\end{array}$ & $\begin{array}{l}2.66 \\
(0.66)\end{array}$ & $\begin{array}{l}2.67 \\
(0.71)\end{array}$ & $\begin{array}{l}2.68 \\
(0.65)\end{array}$ & $\begin{array}{l}2.71 \\
(0.75)\end{array}$ \\
\hline 13. Share of Students with Missing Score & 0.10 & 0.07 & 0.08 & 0.06 \\
\hline 14. Share of Missing Students Identified as Exceptional & 0.25 & 0.13 & 0.29 & 0.15 \\
\hline 15. Share Included in Analysis Sample & 0.73 & 0.70 & 0.95 & 0.91 \\
\hline
\end{tabular}

Notes: based on standardized tests administered in 1998-2005 to students in Grades 3 and 6. 


\section{Appendix Table 5: Statistics on Circles Around Opening and Closing Schools}

\begin{tabular}{|c|c|c|c|c|c|}
\hline Panel A & $\begin{array}{c}\text { Total number } \\
\text { of events }\end{array}$ & $\begin{array}{l}\text { Number with } \\
\text { NO nearby } \\
\text { school }\end{array}$ & $\begin{array}{l}\text { Number with at } \\
\text { least one non- } \\
\text { rural school }\end{array}$ & & \\
\hline 1. Public School Opening & 252 & 58 & 159 & & \\
\hline 2. Separate School Opening & 169 & 34 & 107 & & \\
\hline 3. Public School Closure & 212 & 74 & 97 & & \\
\hline 4. Separate School Closure & 102 & 10 & 79 & & \\
\hline $\begin{array}{l}\text { Panel B: Characteristics } \\
\text { of Circles That Include } \\
\text { Non-Rural Affected } \\
\text { Schools }\end{array}$ & $\begin{array}{l}\text { Percent with } \\
\text { 1+ Public } \\
\text { Schools }\end{array}$ & $\begin{array}{l}\text { Percent with } \\
\text { 1+ Separate } \\
\text { Schools }\end{array}$ & $\begin{array}{l}\text { Percent that } \\
\text { have at least } 1 \\
\text { school in intial } \\
\text { circle dropped }\end{array}$ & $\begin{array}{l}\text { Percent that } \\
\text { have at least } 1 \\
\text { school outside } \\
\text { intial circle } \\
\text { added }\end{array}$ & $\begin{array}{l}\text { Percent that } \\
\text { have all } \\
\text { included } \\
\text { schools } \\
\text { outside intial } \\
\text { circle }\end{array}$ \\
\hline 1. Public School Opening & $86.2 \%$ & $92.5 \%$ & $23.9 \%$ & $54.7 \%$ & $13.8 \%$ \\
\hline 2. Separate School Opening & $87.9 \%$ & $72.9 \%$ & $20.6 \%$ & $64.5 \%$ & $16.8 \%$ \\
\hline 3. Public School Closure & $96.9 \%$ & $94.8 \%$ & $64.9 \%$ & $43.3 \%$ & $5.2 \%$ \\
\hline 4. Separate School Closure & $100.0 \%$ & $81.0 \%$ & $62.0 \%$ & $49.4 \%$ & $1.3 \%$ \\
\hline
\end{tabular}


Figure 1: Public and Separate Schools, West of Toronto

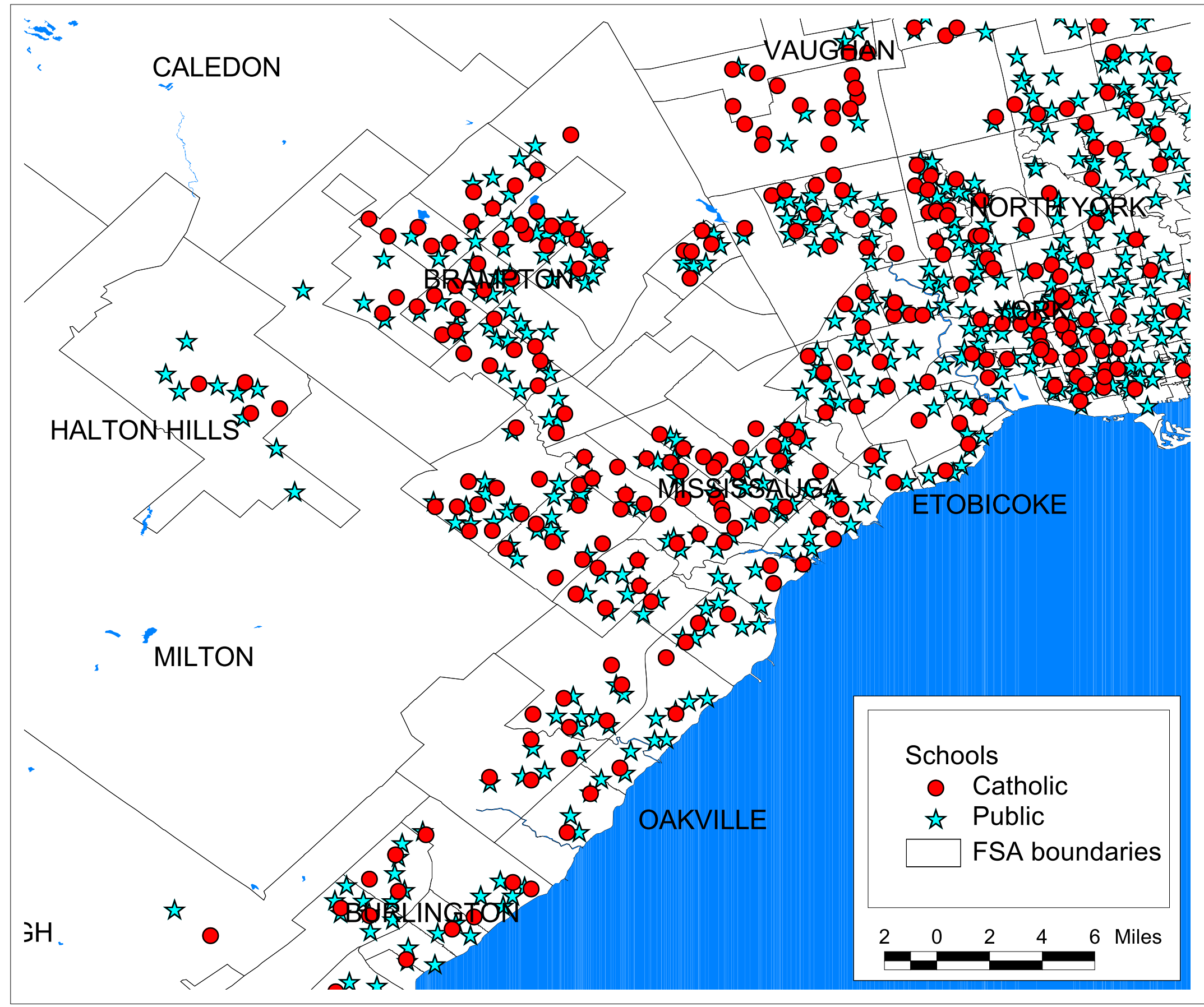


Table 1: Summary Statistics on Opening and Closing Schools and Affected Schools

Panel A: Statistics on Schools that Open or Close

\begin{tabular}{|c|c|c|c|c|c|}
\hline & \multirow[b]{2}{*}{$\begin{array}{l}\text { Total } \\
\text { Number of } \\
\text { Events } \\
(1)\end{array}$} & \multirow[b]{2}{*}{$\begin{array}{c}\text { Share of } \\
\text { Events } 1998 \\
\text { or Later } \\
(2)\end{array}$} & \multirow[b]{2}{*}{$\begin{array}{l}\text { Share with } \\
\text { 1+ Nearby } \\
\text { Non-Rural } \\
\text { Schools } \\
(3)\end{array}$} & \multicolumn{2}{|c|}{ Mean Enrollment: } \\
\hline & & & & $\begin{array}{l}\text { At Schools with } \\
1 \text { or More } \\
\text { Nearby Non- } \\
\text { Rural Schools } \\
(4)\end{array}$ & $\begin{array}{l}\text { At Schools } \\
\text { without a } \\
\text { Nearby Non- } \\
\text { Rural School } \\
\text { (5) }\end{array}$ \\
\hline 1. Public Opening & 252 & 0.599 & 0.631 & 303.9 & 282.8 \\
\hline 2. Separate Opening & 169 & 0.604 & 0.633 & 315.5 & 285.8 \\
\hline 3. Public Closing & 212 & 0.717 & 0.458 & 228.9 & 208.5 \\
\hline 4. Separate Closing & 102 & 0.765 & 0.775 & 247.4 & 185.9 \\
\hline
\end{tabular}

Note: see text for definitions. Enrollment measure used in columns 4-5 is maximum combined enrollment in grades 1-6 observed at opened or closed school during sample period.

Panel B: Mean Distance to Non-Rural Affected Schools (kilometers)

\begin{tabular}{|c|c|c|c|}
\hline & \multicolumn{3}{|c|}{ Mean Distance to: } \\
\hline & $\begin{array}{l}\text { All Affected } \\
\text { Schools } \\
(1)\end{array}$ & $\begin{array}{l}\text { Affected } \\
\text { Public } \\
\text { Schools } \\
(2) \\
\end{array}$ & $\begin{array}{c}\text { Affected } \\
\text { Separate } \\
\text { Schools } \\
\text { (3) }\end{array}$ \\
\hline $\begin{array}{l}\text { 1. Distance to Newly Opened Public School } \\
\text { (number of schools) }\end{array}$ & $\begin{array}{l}1.12 \\
(473)\end{array}$ & $\begin{array}{l}1.21 \\
(244)\end{array}$ & $\begin{array}{l}1.02 \\
(229)\end{array}$ \\
\hline $\begin{array}{l}\text { 2. Distance to Newly Opened Separate Schoo } \\
\text { (number of schools) }\end{array}$ & $\begin{array}{l}1.21 \\
(261)\end{array}$ & $\begin{array}{l}1.13 \\
(168)\end{array}$ & $\begin{array}{l}1.06 \\
(93)\end{array}$ \\
\hline $\begin{array}{l}\text { 3. Distance to Newly Closed Public School } \\
\text { (number of schools) }\end{array}$ & $\begin{array}{l}1.07 \\
(414)\end{array}$ & $\begin{array}{l}1.12 \\
(244)\end{array}$ & $\begin{array}{c}0.98 \\
(170)\end{array}$ \\
\hline $\begin{array}{l}\text { 4. Distance to Newly Closed Separate School } \\
\text { (number of schools) }\end{array}$ & $\begin{array}{l}0.957 \\
(330)\end{array}$ & $\begin{array}{l}0.908 \\
(220) \\
\end{array}$ & $\begin{array}{l}1.055 \\
(110)\end{array}$ \\
\hline
\end{tabular}

Panel C: Distribution of Affected Schools by Numbers of Opening/Closing Events

\begin{tabular}{lcccc}
\hline & \multicolumn{4}{c}{ Type of Event: } \\
\cline { 2 - 4 } & $\begin{array}{c}\text { Public } \\
\text { Opening }\end{array}$ & $\begin{array}{c}\text { Separate } \\
\text { Opening }\end{array}$ & Public Close & Separate Close \\
\hline 1. Total Number of Schools & 159 & 107 & 97 & 79 \\
2. Number of Non-rural Schools Affected: & & & & \\
\hline One School & 24 & 24 & 6 & 9 \\
Two Schools & 49 & 38 & 15 & 22 \\
Three Schools & 31 & 25 & 27 & 15 \\
Four Schools & 28 & 15 & 16 & 11 \\
Five Schools & 21 & 4 & 3 & 7 \\
Six Schools & 2 & 1 & 13 & 11 \\
Seven or More Schools & 4 & 0 & 17 & 9 \\
\hline
\end{tabular}

Note: Counts of opening/closing schools include only those with 1 or more nearby non-rural schools. 
1. Grade 1 Enrollment (Standard Deviation)

Number of Observations

2. Proportional Change in Grade 1 Enrollment from

Previous Year to Current Year

(Standard Deviation)

Number of Observations

3. Proportional Change in Enrollment from Grades 1-5 Previous Year to Grades 2-6 Current Year (Standard Deviation)
50.4

7,554

1.87

(26.41)

6,994
44.3

5,290

2.38

4,893

Number of Observations

0.13

(17.35)

7,067
0.42

4,940

Note: sample includes school-year observations for non-rural elementary schools affected by at least one opening or closing of nearby school over the sample period (1990-2004). 
Enrollment Growth Measure

Change in 1st

Grade Enrollment Change in Enrollment from Grades 1-5 in Year (t-1) to Grades 2-6 in Year (t)

Own-System Effects:
1. Effect of Public Opening on Nearby Public School

2. ... Interacted with Share New Housing Stock in FSA

(1)

$-7.8$

(2)

(3)

$-6.3$

4. ...Interacted with Share New Housing Stock in FSA

$-7.8$

$-6.3$

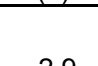

(4)

$(5)$

$\begin{array}{ccc}(5) & (6) & (7) \\ -6.3 & -2.9 & -2.9 \\ (0.7) & (1.2) & (1.2) \\ - & -12.8 & -12.8 \\ & (4.1) & (4.1) \\ -9.5 & -9.1 & -9.1 \\ (1.3) & (2.3) & (2.3) \\ - & -1.0 & -1.1 \\ & (5.9) & (5.9)\end{array}$

\section{Cross-System Effects:}

5. Effect of Public Opening on Nearby Separate School

6. ...Interacted with Share New Housing Stock in FSA

7. ...Interacted with Share of Catholics in FSA

8. .... Interacted with share of Catholics in FSA $\times$ Share New Housing Stock in FSA

\section{Effect of Separate Opening on Nearby Public School}

10. ...Interacted with Share New Housing Stock in FSA

11. ...Interacted with Share of Catholics in FSA

12. ...Interacted with share of Catholics in FSA $\times$ Share New Housing Stock in FSA

Own-system and cross-system closing effects School fixed effects and Year Dummies

Time-varying school characteristics

Time-varying local characteristics

Number of observations

(1.2)

$(0.7)$

$-$

(2.0)

-9.6
$(1.3)$

$-9.0$

-9.0
$(2.3)$

$-1.4$

-9.5
$(1.3)$

$-$

Number of schools

$\begin{array}{ll}-2.0 & -1 \\ (1.3) & (0.6) \\ - & \\ - & \\ -3.3 \\ (1.5) \\ - \\ -\end{array}$

$\begin{array}{cc}-1.1 & 1.1 \\ (0.6) & (0.9) \\ - & -7.4 \\ & (2.5)\end{array}$

1.1
$(0.9)$
-7.4
$(2.5)$

0.1

(2.2)

$-$

$-3.2$

(5.9)

- $\quad-$

$-$

$\begin{array}{cc}-2.9 & 1.7 \\ (0.9) & (2.0) \\ - & -14.2 \\ & (7.3)\end{array}$

$-3.0$

(4.2)

$-$

$-$
0.4
(12.0)

$$
-7.7
$$

-3.0
$(1.7)$

2.3

$-15.6$

-15.6
$(6.8)$

$-11.1$

$\begin{array}{rr}- & -15.6 \\ & (6.8)\end{array}$

(4.4)$$
\text { - }
$$$$
-
$$$$
-
$$

\begin{tabular}{|c|c|c|c|c|c|c|}
\hline & & & & & $\begin{array}{l}-42.9 \\
(19.0)\end{array}$ & $\begin{array}{l}-21.4 \\
(9.2)\end{array}$ \\
\hline Yes & Yes & Yes & Yes & Yes & Yes & Yes \\
\hline Yes & Yes & Yes & Yes & Yes & Yes & Yes \\
\hline Yes & Yes & Yes & Yes & Yes & Yes & Yes \\
\hline Yes & Yes & Yes & Yes & Yes & Yes & Yes \\
\hline 1,887 & 12,007 & 12,007 & 12,007 & 12,007 & 12,007 & 12,007 \\
\hline 939 & 945 & 945 & 945 & 945 & 945 & 945 \\
\hline
\end{tabular}

Note: standard errors in parentheses. School characteristics are a dummy for being paired with another school for administrative purposes. Local characteristics are share of enrolled students in the FSA attending public French and private schools, total population in the FSA and shares of population ages 5-9 and 10-14, fraction of FSA residents who are Catholic, fraction who are immigrants, fractions of FSA residents of East Asian, South Asian, and Northern, Southern, and Eastern European ancentry, fraction of population with a university degree, fraction with no high school degree, fraction of single-headed families, fraction of families with 2 or 3 kids, and fraction of adults with home language other than English. British or French ancentry treated as equivalent to "Canadian". Eastern European ancentry groups includes countries formerly affiliated with the U.S.S.R. 


\section{Public Schools \\ Grade 3}

(1)

Grade 6

(2)

Test-Taker Characteristics for Students with At Least One Test Score:

1. Number of observations

2. Share Female

3. Share missing Gender

4. Share ESL Students

5. Share Exceptional Students

6. Share Attended Kindergarden

7. Share Missing Kindergarden Information

8. Share French Immersion Students

9. Share Gifted Students

10. Share with Scores for All Three Tests

\section{Reading Tests}

11. Number of observations

12. Average Score (1-4 Scale) (standard deviation)

13. Share of Students with Missing Score

14. Share of Missing Students Identified as Exceptional

Mathematics Tests

15. Number of observations

16. Average Score (1-4 Scale) (standard deviation)

17. Share of Students with Missing Score

18. Share of Missing Students Identified as Exceptional

\section{Writing Tests}

19. Number of observations

20. Average Score (1-4 Scale) (standard deviation)

21. Share of Students with Missing Score

22. Share of Missing Students Identified as Exceptional
323,508

0.49

0.01

0.06

0.04

0.86

0.06

0.09

0.01

0.64

212,761

2.52

$(0.76)$

0.13

0.23

230,562

2.73

(0.75)

0.09

0.23

219,835

2.66

(0.66)

0.10

0.25
340,259

0.49

0.01

0.05

0.04

0.73

0.24

0.06

0.02

0.65

229,650

2.68

(0.74)

0.09

0.12

238,153

2.71

(0.80)

0.08

0.12

233,759

2.67

(0.71)

0.07

0.14
164,502

0.49

0.01

0.02

0.03

0.89

0.04

0.04

0.001

0.87

147,721

2.52

(0.75)

0.10

0.26

153,117

2.68

(0.73)

0.08

0.28

151,622

2.69

(0.65)

0.08

0.29
172,409

0.49

0.005

0.02

0.03

0.75

0.23

0.04

0.01

0.86

152,638

2.70

(0.73)

0.07

0.14

154,042

2.68

(0.79)

0.06

0.14

154,773

2.71

(0.69)

0.06

0.15

Notes: based on standardized tests administered in 1998-2005 to students in Grades 3 and 6 . Student observations are included for school-cohorts that have at least 10 test takers in grade 3 and 3 years later in grade 6 , with the ratio of the number of test takers in grade 6 to the number in grade 3 between 0.71 and 1.40 . 
Table 5: Relationship Between Religion and Education/Earnings Among Ontario Parents

\begin{tabular}{|c|c|c|c|c|c|c|c|c|}
\hline & \multicolumn{4}{|c|}{ Dependent Variable $=$ Years Education } & \multicolumn{4}{|c|}{ Dependent Variable $=$ Log Weekly Wages } \\
\hline & \multicolumn{2}{|c|}{ Mothers } & \multicolumn{2}{|c|}{ Fathers } & \multicolumn{2}{|c|}{ Mothers } & \multicolumn{2}{|c|}{ Fathers } \\
\hline & (1) & $(2)$ & (3) & $(4)$ & $(5)$ & $(6)$ & $(7)$ & $(8)$ \\
\hline 1. Catholic & $\begin{array}{c}0.13 \\
(0.07)\end{array}$ & $\begin{array}{l}-0.01 \\
(0.04)\end{array}$ & $\begin{array}{c}0.01 \\
(0.03)\end{array}$ & $\begin{array}{l}-0.06 \\
(0.04)\end{array}$ & $\begin{array}{c}0.04 \\
(0.01)\end{array}$ & $\begin{array}{c}0.02 \\
(0.01)\end{array}$ & $\begin{array}{c}0.03 \\
(0.01)\end{array}$ & $\begin{array}{c}0.00 \\
(0.01)\end{array}$ \\
\hline $\begin{array}{l}\text { 2. Other Religion (not Catholic } \\
\text { or Protestant) }\end{array}$ & - & $\begin{array}{l}-0.20 \\
(0.06)\end{array}$ & - & $\begin{array}{l}0.08 \\
(0.07)\end{array}$ & - & $\begin{array}{l}-0.07 \\
(0.02)\end{array}$ & - & $\begin{array}{l}-0.08 \\
(0.02)\end{array}$ \\
\hline 3. No Religion & - & $\begin{array}{l}-0.44 \\
(0.05)\end{array}$ & - & $\begin{array}{l}-0.32 \\
(0.05)\end{array}$ & - & $\begin{array}{l}-0.04 \\
(0.02)\end{array}$ & - & $\begin{array}{l}-0.06 \\
(0.01)\end{array}$ \\
\hline 4. Dummies for Country of Origin? & Yes & Yes & Yes & Yes & Yes & Yes & Yes & Yes \\
\hline $\begin{array}{l}\text { 5. Dummies for Metro Area } \\
\text { (CMA)? }\end{array}$ & Yes & Yes & Yes & Yes & Yes & Yes & Yes & Yes \\
\hline $\begin{array}{l}\text { 6. Mean of Dependent Variable } \\
\text { [standard deviation] }\end{array}$ & $\begin{array}{l}14.16 \\
{[2.78]}\end{array}$ & $\begin{array}{l}14.16 \\
{[2.78]}\end{array}$ & $\begin{array}{l}14.20 \\
{[2.94]}\end{array}$ & $\begin{array}{l}14.20 \\
{[2.94]}\end{array}$ & $\begin{array}{c}6.21 \\
{[0.83]}\end{array}$ & $\begin{array}{c}6.21 \\
{[0.83]}\end{array}$ & $\begin{array}{c}6.75 \\
{[0.74]}\end{array}$ & $\begin{array}{c}6.75 \\
{[0.74]}\end{array}$ \\
\hline 7. Number of Observations & 31,744 & 31,744 & 27,988 & 27,988 & 22,652 & 22,652 & 23,467 & 23,467 \\
\hline
\end{tabular}

Notes: Sample includes household heads and spouses age 24-64 in households with at least one child age 15 or less living in the province of Ontario in 2001 Canadian Census. Dependent variable in columns 1-4 is estimated years of completed education.

Dependent variable in columns 5-8 is log average weekly wage last year. For specifications in odd-numbered columns omitted religious group is all non-Catholics (including those with no religion). For specifications in even-numbered columns omitted religious group is Protestants. Models are fit by unweighted OLS. Standard errors in parentheses. 


\begin{tabular}{|c|c|c|c|c|c|c|c|c|}
\hline & \multicolumn{4}{|c|}{ All Students } & \multicolumn{4}{|c|}{ Students in Public Schools in 8th Grade } \\
\hline & \multicolumn{2}{|c|}{ 8th Grade Tests } & \multicolumn{2}{|c|}{ Test Gain: 10th-8th } & \multicolumn{2}{|c|}{ 8th Grade Tests } & \multicolumn{2}{|c|}{ Test Gain: 10th-8th } \\
\hline & $(1)$ & $(2)$ & (3) & $(4)$ & $(5)$ & (6) & $(7)$ & $(8)$ \\
\hline 1. Catholic & $\begin{array}{l}120.5 \\
(18.5)\end{array}$ & $\begin{array}{c}33.9 \\
(20.9)\end{array}$ & $\begin{array}{c}37.4 \\
(10.5)\end{array}$ & $\begin{array}{c}17.0 \\
(11.8)\end{array}$ & $\begin{array}{l}102.0 \\
(21.9)\end{array}$ & $\begin{array}{c}14.4 \\
(24.2)\end{array}$ & $\begin{array}{c}35.9 \\
(12.3)\end{array}$ & $\begin{array}{c}14.7 \\
(13.7)\end{array}$ \\
\hline $\begin{array}{l}\text { 2. Other Religion (Not Protestant } \\
\text { or Catholic) }\end{array}$ & - & $\begin{array}{l}-39.0 \\
(22.4)\end{array}$ & - & $\begin{array}{l}-25.3 \\
(12.7)\end{array}$ & - & $\begin{array}{l}-22.3 \\
(24.2)\end{array}$ & - & $\begin{array}{l}-26.4 \\
(13.6)\end{array}$ \\
\hline 3. No Religion & - & $\begin{array}{l}-57.2 \\
(29.3)\end{array}$ & - & $\begin{array}{l}-41.3 \\
(16.6)\end{array}$ & - & $\begin{array}{l}-41.4 \\
(30.7)\end{array}$ & - & $\begin{array}{l}-40.8 \\
(17.3)\end{array}$ \\
\hline 4. Religion Not Reported & - & $\begin{array}{r}-365.7 \\
(23.8)\end{array}$ & - & $\begin{array}{l}-68.9 \\
(16.3)\end{array}$ & - & $\begin{array}{l}-389.0 \\
(25.2)\end{array}$ & - & $\begin{array}{l}-66.5 \\
(17.1)\end{array}$ \\
\hline 5. Controls for Gender, Ethnicity & Yes & Yes & Yes & Yes & Yes & Yes & Yes & Yes \\
\hline $\begin{array}{l}\text { 6. Controls for Urban Location and } \\
\text { Division }\end{array}$ & Yes & Yes & Yes & Yes & Yes & Yes & Yes & Yes \\
\hline $\begin{array}{l}\text { 7. Controls for Parents' Education, } \\
\text { Living with Mother/Father at } \\
\text { 8th Grade, and SES Quartile }\end{array}$ & Yes & Yes & Yes & Yes & Yes & Yes & Yes & Yes \\
\hline $\begin{array}{l}\text { 8. Mean of Dependent Variable } \\
\text { [standard deviation] }\end{array}$ & $\begin{array}{l}5081.1 \\
{[988.5]}\end{array}$ & $\begin{array}{l}5081.1 \\
{[988.5]}\end{array}$ & $\begin{array}{c}-33.3 \\
{[472.4]}\end{array}$ & $\begin{array}{c}-33.3 \\
{[472.4]}\end{array}$ & $\begin{array}{l}4973.6 \\
{[979.4]}\end{array}$ & $\begin{array}{l}4973.6 \\
{[979.4]}\end{array}$ & $\begin{array}{c}-38.1 \\
{[470.1]}\end{array}$ & $\begin{array}{c}-33.3 \\
{[472.4]}\end{array}$ \\
\hline 9. Number of Observations & 13,315 & 13,315 & 12,037 & 12,037 & 11,078 & 11,078 & 9,970 & 9,970 \\
\hline
\end{tabular}

Notes: Dependent variable in columns 1-2 and 5-6 is composite test score (math and reading) in 8th grade. Dependent variable in columns 34 and 7-8 is change in composite test score from 8 th to 10 th grade. Models are fit by unweighted OLS and do not account for NELS sample design. For specifications in odd-numbered columns, omitted religious group is all other religions (including none and not reported). For specification in even-numbered columns, omitted religious group is Protestants (i.e., Baptists, Methodists, Lutherans, Presbyterians, Episcopalians, Pentacostals, and Other Protestants). Missing data for mother's or father's education are allocated and models include dummies for missing data. Standard errors in parentheses. 


\begin{tabular}{|c|c|c|c|c|c|c|c|c|c|c|c|c|}
\hline \multirow{2}{*}{$\begin{array}{l}\text { Dependent Variable: Individual Test Score (4-point } \\
\text { scale from } 1 \text { to } 4 \text {, standard deviation } \approx 0.75 \text { ) }\end{array}$} & \multicolumn{4}{|c|}{ Reading } & \multicolumn{4}{|c|}{ Mathematics } & \multicolumn{4}{|c|}{ Writing } \\
\hline & (1) & $(2)$ & $(3)$ & $(4)$ & $(5)$ & (6) & $(7)$ & (8) & (9) & $(10)$ & $(11)$ & $(12)$ \\
\hline \multicolumn{13}{|l|}{ Local Competition Measures: } \\
\hline 1. Share of Catholics $\times$ Grade 6 & $\begin{array}{c}0.14 \\
(0.05)\end{array}$ & $\begin{array}{c}0.10 \\
(0.06)\end{array}$ & - & - & $\begin{array}{c}0.31 \\
(0.07)\end{array}$ & $\begin{array}{l}0.25 \\
(0.08)\end{array}$ & - & - & $\begin{array}{c}0.13 \\
(0.04)\end{array}$ & $\begin{array}{c}0.10 \\
(0.05)\end{array}$ & - & - \\
\hline $\begin{array}{l}\text { 2. Share of Catholics } \times \text { Share New Housing Stock } \\
\times \text { Grade } 6\end{array}$ & - & $\begin{array}{c}0.28 \\
(0.16)\end{array}$ & $\begin{array}{c}0.39 \\
(0.14)\end{array}$ & $\begin{array}{c}0.35 \\
(0.15)\end{array}$ & & $\begin{array}{c}0.40 \\
(0.23)\end{array}$ & $\begin{array}{c}0.71 \\
(0.20)\end{array}$ & $\begin{array}{c}0.50 \\
(0.21)\end{array}$ & & $\begin{array}{c}0.24 \\
(0.12)\end{array}$ & $\begin{array}{c}0.35 \\
(0.11)\end{array}$ & $\begin{array}{c}0.26 \\
(0.12)\end{array}$ \\
\hline \multicolumn{13}{|l|}{ Other Controls: } \\
\hline 3. Share with No Religion $\times$ Grade 6 & - & - & - & $\begin{array}{l}-0.15 \\
(0.11)\end{array}$ & - & - & - & $\begin{array}{l}-0.65 \\
(0.16)\end{array}$ & - & - & - & $\begin{array}{l}-0.26 \\
(0.09)\end{array}$ \\
\hline 4. Share with Other Religions $\times$ Grade 6 & - & - & - & $\begin{array}{c}0.07 \\
(0.07)\end{array}$ & - & - & - & $\begin{array}{c}0.17 \\
(0.10)\end{array}$ & - & - & - & $\begin{array}{c}0.06 \\
(0.05)\end{array}$ \\
\hline 5. Dummy $=1$ if Test Taker in Grade 6 & $\begin{array}{c}0.02 \\
(0.04)\end{array}$ & $\begin{array}{c}0.04 \\
(0.04)\end{array}$ & $\begin{array}{c}0.08 \\
(0.03)\end{array}$ & $\begin{array}{c}0.10 \\
(0.03)\end{array}$ & $\begin{array}{l}-0.27 \\
(0.05)\end{array}$ & $\begin{array}{l}-0.25 \\
(0.05)\end{array}$ & $\begin{array}{l}-0.14 \\
(0.04)\end{array}$ & $\begin{array}{l}-0.04 \\
(0.05)\end{array}$ & $\begin{array}{l}-0.12 \\
(0.03)\end{array}$ & $\begin{array}{l}-0.11 \\
(0.03)\end{array}$ & $\begin{array}{l}-0.07 \\
(0.02)\end{array}$ & $\begin{array}{l}-0.03 \\
(0.03)\end{array}$ \\
\hline 6. Separate School $\times$ Grade 6 & $\begin{array}{c}0.02 \\
(0.01)\end{array}$ & $\begin{array}{c}0.02 \\
(0.01)\end{array}$ & $\begin{array}{c}0.02 \\
(0.01)\end{array}$ & $\begin{array}{c}0.02 \\
(0.01)\end{array}$ & $\begin{array}{c}0.03 \\
(0.01)\end{array}$ & $\begin{array}{c}0.03 \\
(0.01)\end{array}$ & $\begin{array}{c}0.03 \\
(0.01)\end{array}$ & $\begin{array}{c}0.03 \\
(0.01)\end{array}$ & $\begin{array}{c}0.02 \\
(0.01)\end{array}$ & $\begin{array}{c}0.02 \\
(0.01)\end{array}$ & $\begin{array}{c}0.02 \\
(0.01)\end{array}$ & $\begin{array}{c}0.02 \\
(0.01)\end{array}$ \\
\hline 7. Share of New Housing Stock $\times$ Grade 6 & $\begin{array}{l}-0.01 \\
(0.02)\end{array}$ & $\begin{array}{l}-0.11 \\
(0.06)\end{array}$ & $\begin{array}{l}-0.15 \\
(0.06)\end{array}$ & $\begin{array}{l}-0.15 \\
(0.06)\end{array}$ & $\begin{array}{c}0.06 \\
(0.04)\end{array}$ & $\begin{array}{l}-0.09 \\
(0.09)\end{array}$ & $\begin{array}{l}-0.21 \\
(0.08)\end{array}$ & $\begin{array}{l}-0.16 \\
(0.09)\end{array}$ & $\begin{array}{c}0.02 \\
(0.02)\end{array}$ & $\begin{array}{l}-0.07 \\
(0.05)\end{array}$ & $\begin{array}{l}-0.12 \\
(0.05)\end{array}$ & $\begin{array}{l}-0.10 \\
(0.05)\end{array}$ \\
\hline Student, Peer Group, and Neighborhood Controls & yes & yes & yes & yes & yes & yes & yes & yes & yes & yes & yes & yes \\
\hline School-Cohort Fixed Effects & yes & yes & yes & yes & yes & yes & yes & yes & yes & yes & yes & yes \\
\hline R-Square & 0.16 & 0.16 & 0.16 & 0.16 & 0.18 & 0.18 & 0.18 & 0.18 & 0.16 & 0.16 & 0.16 & 0.16 \\
\hline Number of Observations & & & & & & 775,874 & & & & & ,989 & \\
\hline
\end{tabular}

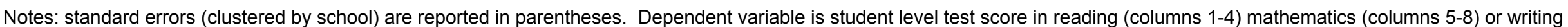

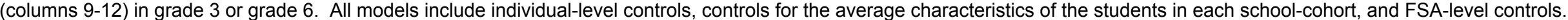
See text for description of additional controls. 